Review

\title{
Exposure to Occupational Hazards among Health Care Workers in Low- and Middle-Income Countries: A Scoping Review
}

\author{
Rajni Rai ${ }^{1, *}$, Sonia El-Zaemey ${ }^{1}$, Nidup Dorji ${ }^{2}{ }^{\mathbb{D}}$, Bir Doj Rai ${ }^{3}$ and Lin Fritschi ${ }^{1}(\mathbb{D}$ \\ 1 School of Public Health, Curtin University, Bentley, WA 6102, Australia; \\ Sonia.El-Zaemey@curtin.edu.au (S.E.-Z.); Lin.Fritschi@curtin.edu.au (L.F.) \\ 2 Faculty of Nursing and Public Health, Khesar Gyalpo University of Medical Sciences of Bhutan, \\ Thimphu 11001, Bhutan; nidupdorji.dorji@gmail.com \\ 3 Regional Livestock Development Centre Wangduephodrang, Wangduephodrang 14001, Bhutan; \\ birdoj_rai@yahoo.com \\ * Correspondence: rajni.rai@postgrad.curtin.edu.au; Tel.: +61-4-16090550
}

Citation: Rai, R.; El-Zaemey, S.; Dorji, N.; Rai, B.D.; Fritschi, L. Exposure to Occupational Hazards among Health Care Workers in Low- and Middle-Income Countries: A Scoping Review. Int. J. Environ. Res. Public Health 2021, 18, 2603. https:// doi.org/10.3390/ijerph18052603

Academic Editor: Paul B. Tchounwou

Received: 19 January 2021

Accepted: 3 March 2021

Published: 5 March 2021

Publisher's Note: MDPI stays neutral with regard to jurisdictional claims in published maps and institutional affiliations.

Copyright: (c) 2021 by the authors. Licensee MDPI, Basel, Switzerland. This article is an open access article distributed under the terms and conditions of the Creative Commons Attribution (CC BY) license (https:/ / creativecommons.org/licenses/by/ $4.0 /)$.
Abstract: Health care workers are exposed to numerous workplace hazards. The implementation of safety measures in high-income countries has largely mitigated these risks. However, in many low- and middle- income countries (LMICs), resources to institute safety measures are lacking, increasing the risk of occupational exposures to these hazards. The aim of this scoping review is to map and synthesize the available research on occupational hazards among health care workers in LMICs, identify research gaps and inform policy. Searches for relevant articles were conducted in five electronic databases using a broad range of search terms. The inclusion criteria were: quantitative observational or experimental studies which examined exposure to one or more occupational hazards among health care workers in a LMCI; and the article was published in English in a peer-reviewed journal. A total of 99 studies met the inclusion criteria, and data were extracted from these studies. Large proportions of health care workers in LMICs were exposed to biological hazards (bloodborne pathogens, tuberculosis), psychosocial hazards (workplace violence, burnout, job dissatisfaction), ergonomic hazards (musculoskeletal complaints), and chemical hazards (exposure to latex and antineoplastic drugs). The implementation of risk reduction strategies was suboptimal. The majority of the literature was on biological hazards (48\%), and research on other hazards was limited in comparison. Occupational safety needs to become a priority public health issue to protect health care workers in LMICs. More research is needed to understand the magnitude of the problem in these countries.

Keywords: occupational hazards; health care workers; low- and middle-income countries

\section{Introduction}

Health care workers are at potential risk of harm from exposure to numerous hazardous agents encountered in their workplace [1]. The most recent and visible example is the ongoing COVID-19 pandemic, which has showcased the vulnerability of health care workers and demonstrated the importance of ensuring their safety [2].

In addition to exposures to emerging diseases, health care workers are routinely exposed to other infectious agents such as tuberculosis, influenza, HIV, and Hepatitis $B$, which have been the primary focus of research and safety programs [3]. Health care workers are also exposed to various chemical hazards and agents that have been linked to long-term adverse health effects. Chemicals used in health care settings such as ethylene oxide, formaldehyde, and antineoplastic drugs have been linked to cancers and adverse reproductive outcomes [4-6]. Exposure to latex and cleaning and disinfecting agents has been associated with occupational asthma among health care workers [7,8]. Musculoskeletal disorders and injuries, and various psychosocial hazards such as workplace 
violence, stress, and burnout are other well-recognised occupational hazards among health care workers [9-11].

Recognising these risks, safety measures and standards to protect health care workers have been instituted in high-income countries and have largely succeeded in mitigating these hazards [12]. However, in many low- and middle-income countries (LMICs), occupational health and safety is often neglected [13]. These deficiencies in occupational health have been attributed to a lack of political commitment, insufficient resources, poor data collection systems, and weak enforcement of regulations. Occupational health research has shown that providing a safe work environment increases organizational commitment and worker retention [14]. Poor working conditions and threats to health have been reported to contribute to problems in recruitment and retention of health care workers in LMICs, augmenting the issue of health care worker shortages in these countries [15].

In order to institute any prevention and safety intervention, it is important to understand the magnitude of the problem. The majority of the literature on occupational hazards in health care workers has originated in high-income countries, and research from LMICs on this topic is reported to be limited [16]. Findings from studies conducted in high-income countries cannot be generalised to LMICs because exposures in LMICs are likely to be different from high-income countries due to differences in legislation and regulations, health care systems, work practices and the availability of control measures. There is a need to determine the scope and volume of available research conducted on this topic in LMICs and to identify any research gaps. Apart from a narrative literature review conducted in 2016, which was limited in scope and included only 46 studies, there are no other reviews available on this topic [16].

Scoping reviews have been described by Arksey and O'Malley as those which "aim to map rapidly the key concepts underpinning a research area and the main sources and types of evidence available, and can be undertaken as standalone projects in their own right, especially where an area is complex or has not been reviewed comprehensively before" [17]. A revised definition of scoping reviews was proposed by Daudt et al. as "scoping studies aim to map the literature on a particular topic or research area and provide an opportunity to identify key concepts, gaps in literature; and types and sources of evidence to inform practice, policymaking, and research" [18]. Therefore, a scoping review was conducted to map and synthesize the available research on exposure to occupational hazards among health care workers in LMICs, to identify any research gaps and to inform policy to improve the safety of health care workers.

\section{Methods}

This review was conducted according to the methodological framework for scoping reviews outlined by Arksey and O'Malley [17], Levac et al. [19], Colquhan et al. [20], and The Joanna Briggs Institute [21]. It is reported in accordance with the Preferred Reporting Items for Systematic reviews and Meta-Analyses extension for Scoping Reviews (PRISMAScR) [22]. It was guided by the research question 'What is known from the existing literature about exposure to occupational hazards among health care workers in LMICs?'

\subsection{Search Strategy}

The key terms relating to the research question were identified as follows: 'health care workers', 'health workers', 'health personnel', 'health professionals', 'nurses', 'doctors', 'laboratory workers' 'occupational hazards', 'occupational risks', 'occupational diseases', 'occupational health', 'occupational injuries', 'occupational accidents', 'low-and-middleincome countries', 'low-income countries', and 'developing countries'. The search strategy was developed by the research team in consultation with an academic librarian. Using these key terms and their associated mapped subject headings and MeSH terms, searches were conducted in the electronic databases MEDLINE, Scopus, CINAHL, Embase, and PsycINFO till 1 May 2020 (Table S1. Search strategy for Medline (Ovid) (date of search: 1 May 2020)). Original peer-reviewed articles in the English language were the only limits 
applied to the searches to maintain a breadth of coverage. Bibliographies of the included studies were also checked to ensure that all relevant studies had been included in the review. Grey literature was not included.

\subsection{Study Selection}

Studies were selected based on the following inclusion criteria: (1) participants were health care workers as classified by the World Health Organization (WHO) [23], (2) the study was conducted in a low- and middle- (both lower- and upper-) income country as classified by the World Bank classification of countries, 2020 [24], (3) the study topic was on exposure to occupational hazards, (4) the type of study was a quantitative observational or experimental study, and (5) the article was published in English in a peer-reviewed journal. Studies were excluded if they were qualitative in design, case series or case reports, reviews, conference presentations or dissertations. The only exception to the application of the selection criteria was on studies on tuberculosis. For tuberculosis, since a systematic review on tuberculosis among health care workers in LMICs had been published in 2006 [25], only studies conducted after this period on this topic were included. Studies on night shift work were also excluded.

After removing duplicates, one reviewer (RR) assessed the articles by titles and abstracts and applied the inclusion and exclusion criteria to select the full-text articles to be retrieved. Any uncertainties related to study selection at this stage was discussed with the research team till a consensus was reached. Full-text articles were then screened independently by two reviewers (RR and SE-Z) to finalize their inclusion in the review. Any disagreement regarding the determination of study inclusion in the review at this stage was resolved by consulting a third reviewer (LF). Manual searches of the reference lists of included studies were also conducted.

\subsection{Charting of the Data}

Data were extracted from the studies and charted on a table by one reviewer (RR). This included author, year of publication, country of study origin, aims, study population and sample size, study design and methodology, and key findings. A second reviewer (LF) then extracted data from ten randomly selected studies using the data charting form to ensure that the data extraction approach was consistent with the research question and study aims.

\subsection{Collating and Summarising the Results}

The study characteristics, which included the year of publication, study design and methodology, location, participant characteristics, the topic researched, and the study outcomes, were first tabulated. This was performed to provide a descriptive numerical summary of the studies included in the review. A thematic analysis was then carried out, and the studies were sorted into occupational hazards groups based on the WHO classification of occupational hazards in health care workers [26]. These two steps assisted in identifying the dominant areas of research, their location and methodology and any research gaps. The findings are then described as a narrative review.

\section{Results}

The database searches identified 609 articles, with a further 37 articles identified from a search of reference lists (Figure 1). After removing duplicates, 330 articles were screened by titles followed by abstract examinations of 141 articles. The review of abstracts resulted in 110 articles for full-text examination, of which 99 articles met the inclusion criteria and were included in the review. 


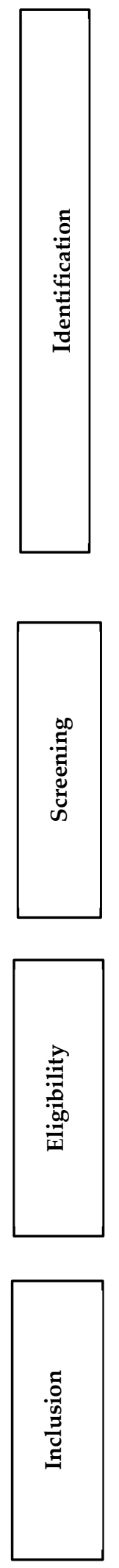

Articles identified through database searches $(n=609)$

$$
\begin{gathered}
\text { Medline-170 } \\
\text { Scopus-229 } \\
\text { CINAHL-131 } \\
\text { Embase-69 }
\end{gathered}
$$

Articles after removing duplicates $(n=330)$

$$
\begin{gathered}
\text { Medline-130 } \\
\text { Scopus-119 } \\
\text { CINAHL-15 } \\
\text { Embase-28 } \\
\text { PsychInfo-1 }
\end{gathered}
$$
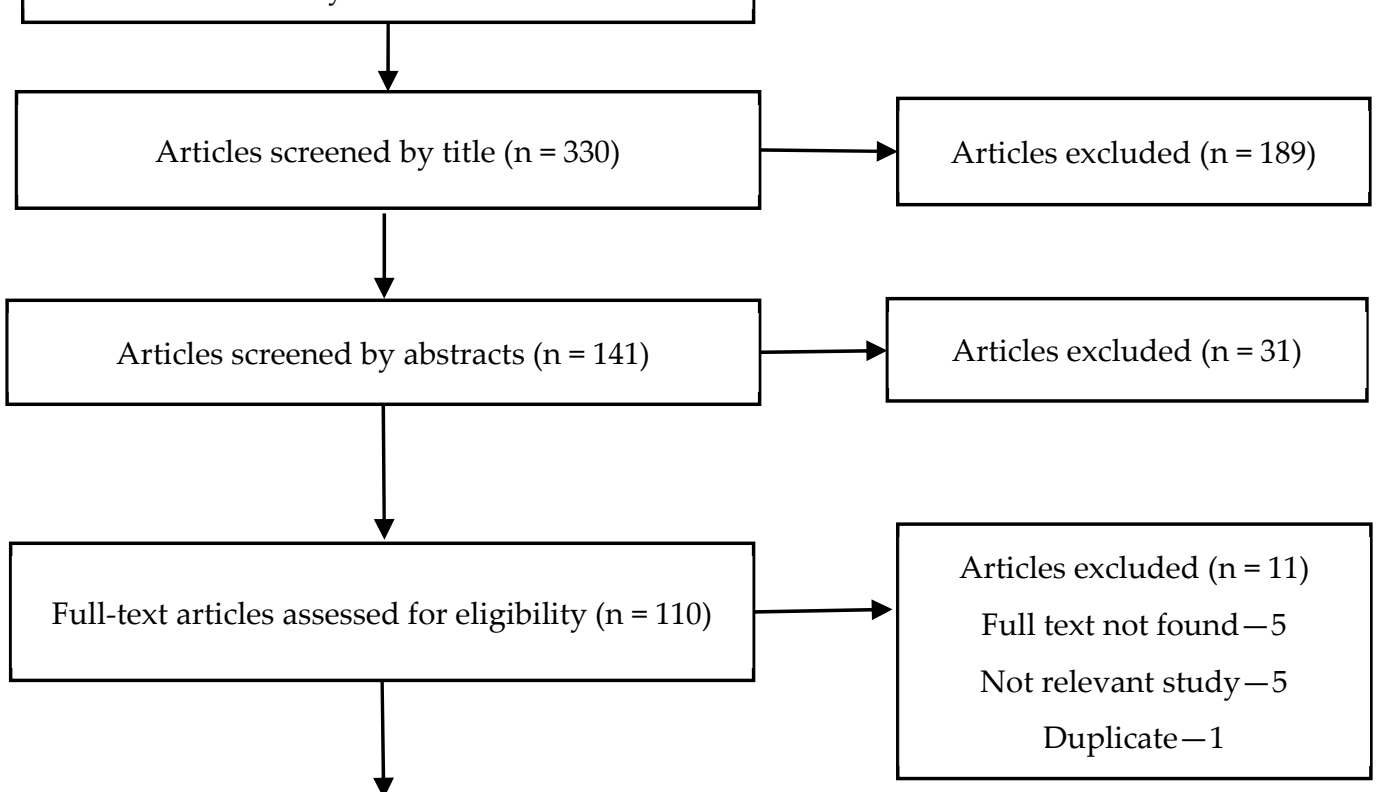

Articles that were eligible $(n=99)$

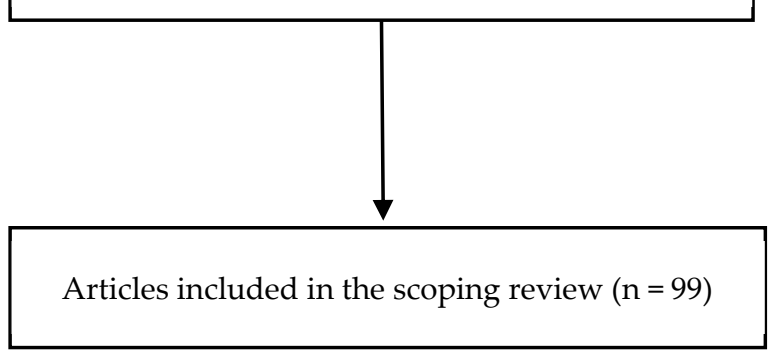

Figure 1. Flow chart illustrating the scoping review study selection process.

The majority of the studies (34 of 99) were conducted in the Sub-Saharan African region (according to the World Bank regions), were cross-sectional in design (82), and participants were all health care workers (51) (Figure 2). Fifty one studies were conducted 
in district/state hospitals and primary care centres, and 48 were conducted in tertiary care centres. The included studies were published after 1991, with six studies published in the 1990s, 31 studies published between 2001 and 2010, and 62 studies between 2011 and 2020 (Figure 3).

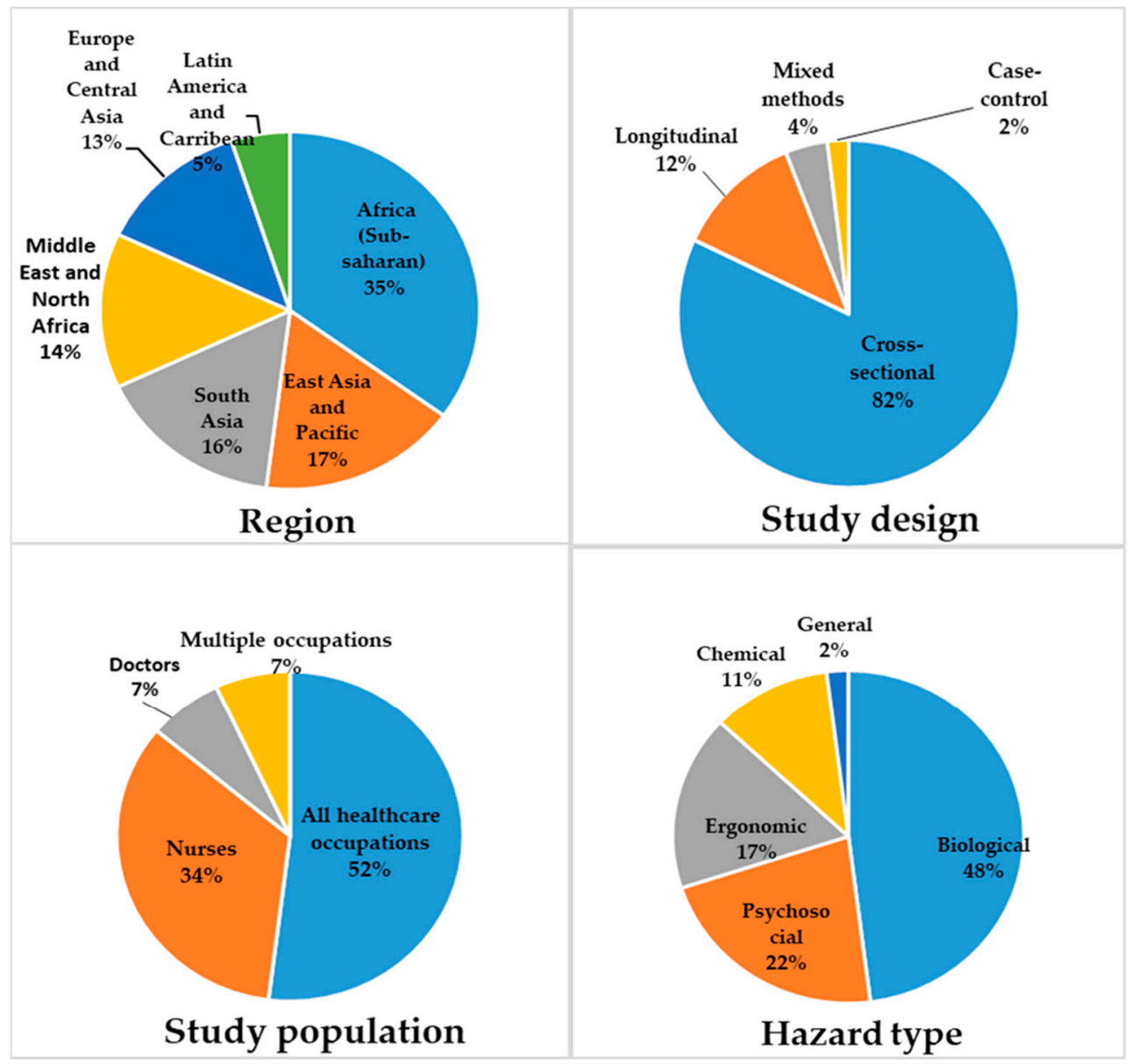

Figure 2. Characteristics of studies.

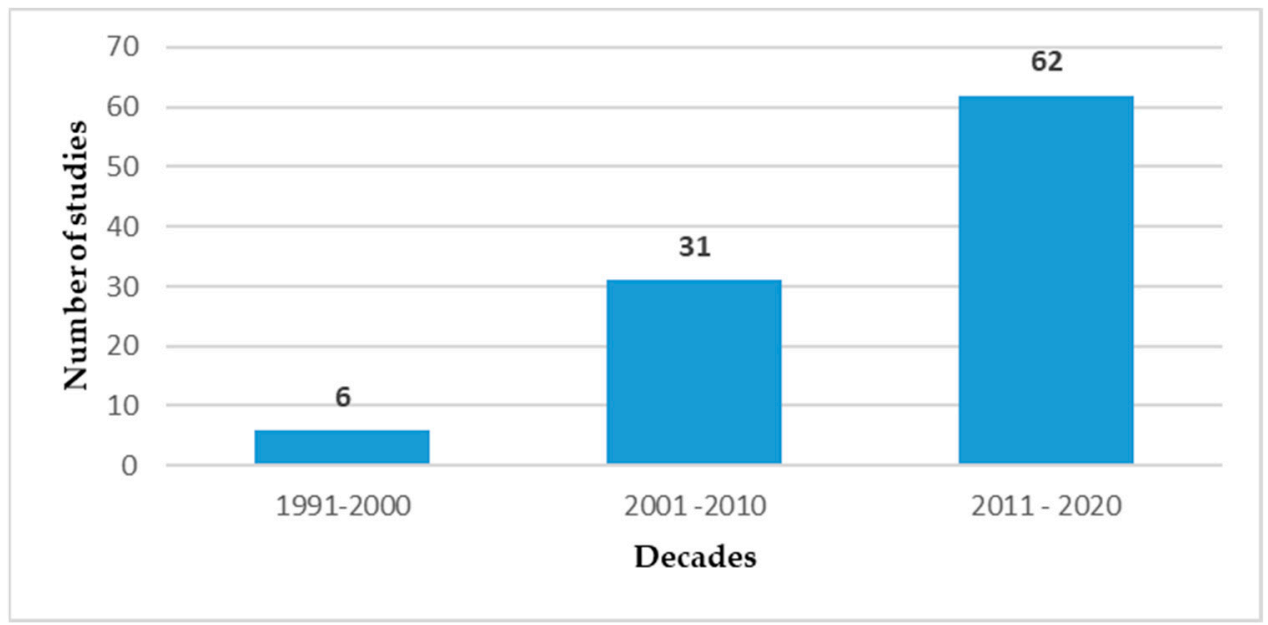

Figure 3. Number of studies by a decade of publication.

Almost half the studies (47) were on biological hazards, 22 studies were on psychosocial hazards, 17 were on ergonomic hazards, and 11 were on chemical hazards (Figure 2). In addition, there were two studies that investigated the different types of occupational 
hazards in general. Among the studies on biological hazards, the majority (38/47) examined exposure to bloodborne pathogens and nine studies (after 2006) examined exposure to tuberculosis (Table 1). Among the studies on psychosocial hazards, 12 studies examined workplace violence and safety climate, six studies examined the prevalence of burnout and its risk factors and four studies examined work environment and job satisfaction (Table 2). The studies on ergonomic hazards mainly investigated the prevalence of musculoskeletal complaints and their risk factors (Table 3). Among the studies on chemical hazards, six studies examined exposure to latex, and five examined exposure to antineoplastic drugs (Table 4). 
Table 1. The characteristics of the studies $(n=47)$ on exposure to biological hazards (arranged in chronological order according to the year of publication).

\begin{tabular}{|c|c|c|c|c|c|c|c|}
\hline Authors & Year & Topic & Origin & Participants & Type of Study & Methods & Findings \\
\hline \multicolumn{8}{|c|}{ I. Bloodborne Pathogens } \\
\hline $\begin{array}{l}\text { Cavalcante } \\
\text { et al. [27] }\end{array}$ & 1991 & $\begin{array}{l}\text { Occupational risk of } \\
\text { acquiring HIV }\end{array}$ & Brazil & $\begin{array}{l}651 \text { health care } \\
\text { workers from a } \\
\text { teaching } \\
\text { hospital }\end{array}$ & Prospective & $\begin{array}{l}\text { Health care workers who } \\
\text { reported accidental } \\
\text { exposures to infective } \\
\text { material from AIDS } \\
\text { patients to the Infection } \\
\text { Control Committee } \\
\text { ( } \mathrm{n}=247 \text { ) and those who } \\
\text { had other risks of infection } \\
\text { but no occupational } \\
\text { exposures ( } \mathrm{n}=404 \text { ) were } \\
\text { interviewed and blood } \\
\text { was collected for HIV } \\
\text { testing at baseline, } 90,180 \\
\text { and } 360 \text { days later (for } \\
\text { health care workers who } \\
\text { reported accidents). }\end{array}$ & $\begin{array}{l}247 \text { health care workers reported } 338 \\
\text { accidents and of these } 115 \text { were followed } \\
\text { up for more than } 6 \text { months and } 132 \text { were } \\
\text { lost to follow up. None tested positive for } \\
\text { HIV. } 50 \% \text { of exposures occurred through } \\
\text { needlestick or sharp injuries, } 22 \% \text { through } \\
\text { contact of blood on mucous membranes, } \\
28 \% \text { through exposures to urine, faeces or } \\
\text { cerebrospinal fluid from AIDs patients. The } \\
\text { highest frequencies of injuries were } \\
\text { reported by nurses, followed by physicians, } \\
\text { laundry and housekeeping personnel and } \\
\text { laboratory workers. Of the } 404 \text { health care } \\
\text { workers with no occupational exposures, } \\
6 \text { were positive and had confirmed risk } \\
\text { factors for HIV transmission. }\end{array}$ \\
\hline $\begin{array}{l}\text { Adegboye } \\
\text { et al. [28] }\end{array}$ & 1994 & $\begin{array}{l}\text { Needlestick and } \\
\text { sharp object injuries } \\
\text { and accidents; } \\
\text { awareness of the risk } \\
\text { of occupational } \\
\text { exposure to HIV }\end{array}$ & Nigeria & $\begin{array}{l}474 \text { health care } \\
\text { workers } \\
\text { working in a } \\
\text { university } \\
\text { hospital } \\
\text { complex, who } \\
\text { were } \\
\text { occupationally } \\
\text { exposed to } \\
\text { blood }\end{array}$ & Cross-sectional & $\begin{array}{l}\text { Questionnaires on } \\
\text { needlestick and sharp } \\
\text { injuries in the past year } \\
\text { and on knowledge on HIV } \\
\text { transmission. }\end{array}$ & $\begin{array}{l}27 \% \text { of health care workers reported at least } \\
\text { one needlestick injury in the past year. } \\
\text { Circumstances resulting in needlestick } \\
\text { injuries were unexpected patient movement } \\
(29 \%) \text {, handling or disposal of used needles } \\
(23 \%) \text {, needle recapping }(18 \%) \text {, accidental } \\
\text { stick by a colleague }(18 \%) \text {, and needle } \\
\text { disassembly }(10 \%) .15 \% \text { reported at least } \\
\text { one sharp object injury in the past year and } \\
\text { this most commonly involved broken glass } \\
\text { from patient specimen containers ( } 39 \%) \text {.The } \\
\text { highest frequencies of injuries were } \\
\text { reported by dental staff and surgeons. } \\
\text { Almost all participants were aware of the } \\
\text { risk of occupational exposure to HIV. }\end{array}$ \\
\hline
\end{tabular}


Table 1. Cont

\begin{tabular}{|c|c|c|c|c|c|c|c|}
\hline Authors & Year & Topic & Origin & Participants & Type of Study & Methods & Findings \\
\hline $\begin{array}{c}\text { Olubuyide } \\
\text { [29] }\end{array}$ & 1996 & $\begin{array}{l}\text { Contact with HIV } \\
\text { and Hepatitis B } \\
\text { (HBV)-positive } \\
\text { patients and } \\
\text { needlestick injuries }\end{array}$ & Nigeria & $\begin{array}{l}149 \text { resident } \\
\text { doctors in a } \\
\text { teaching } \\
\text { hospital in } \\
\text { Nigeria }\end{array}$ & Cross-sectional & $\begin{array}{l}\text { Questionnaire asking } \\
\text { about contact with } \\
\text { HIV/HBV patients, } \\
\text { needlestick injuries, and } \\
\text { precautions used. No time } \\
\text { period was reported. }\end{array}$ & $\begin{array}{l}93 \% \text { reported contact with } \mathrm{HIV} / \mathrm{HBV} \\
\text { patients, } 9 \% \text { had needlestick injuries } \\
\text { (presumably lifetime) and } 54 \% \text { used } \\
\text { universal precautions when performing } \\
\text { procedures. }\end{array}$ \\
\hline $\begin{array}{l}\text { Gumodoka } \\
\text { et al. [30] }\end{array}$ & 1997 & $\begin{array}{l}\text { Injuries and use of } \\
\text { personal protective } \\
\text { equipment (PPE) to } \\
\text { protect from HIV }\end{array}$ & $\begin{array}{l}\text { United } \\
\text { Republic of } \\
\text { Tanzania }\end{array}$ & $\begin{array}{l}403 \text { health care } \\
\text { workers from } \\
\text { nine hospitals } \\
\text { in the Mwanza } \\
\text { region }\end{array}$ & Mixed methods & $\begin{array}{l}\text { Questionnaires on the use } \\
\text { of PPE and needlestick } \\
\text { injuries and splashes. } \\
\text { Observations and } \\
\text { interviews were carried } \\
\text { out in different sections of } \\
\text { the hospitals to determine } \\
\text { general hygiene practices. }\end{array}$ & $\begin{array}{l}\text { Prick and splash incidents were reported } \\
\text { frequently (at least } 5 \text { pinprick accidents and } \\
\text { nine splashes per health care worker per } \\
\text { year). The general hygiene measures to } \\
\text { reduce the risk of HIV was not sufficient } \\
\text { and PPE was not used consistently. }\end{array}$ \\
\hline $\begin{array}{l}\text { Khuri-Bulos } \\
\text { et al. [31] }\end{array}$ & 1997 & $\begin{array}{l}\text { Needlestick and } \\
\text { sharp injuries }\end{array}$ & Jordan & $\begin{array}{l}248 \text { health care } \\
\text { workers } \\
\text { working in a } \\
\text { tertiary care } \\
\text { hospital }\end{array}$ & Prospective & $\begin{array}{l}\text { Surveillance of sharps } \\
\text { injuries over a } 3 \text { year } \\
\text { period. Health care } \\
\text { workers who reported } \\
\text { sharps injuries during this } \\
\text { period completed a } \\
\text { questionnaire. Serum } \\
\text { samples were collected at } \\
\text { baseline and } 6 \text { months } \\
\text { later to be tested for } \\
\text { Hepatitis B, C and HIV. }\end{array}$ & $\begin{array}{l}\text { Over the } 3 \text { year period, } 248 \text { health care } \\
\text { workers reported needlestick injuries. } \\
\text { Highest frequencies were reported by } \\
\text { nurses }(34.6 \%) \text {. The total average annual } \\
\text { rate was } 82: 1000 \text { health care workers per } \\
\text { year. } \\
\text { Only a minority of health care workers } \\
\text { submitted a serum sample. }\end{array}$ \\
\hline $\begin{array}{l}\text { Gounden and } \\
\text { Moodley [32] }\end{array}$ & 2000 & $\begin{array}{l}\text { Injuries and use of } \\
\text { personal protective } \\
\text { equipment to protect } \\
\text { from HIV }\end{array}$ & South Africa & $\begin{array}{l}265 \text { health care } \\
\text { workers from a } \\
\text { tertiary care } \\
\text { hospital }\end{array}$ & $\begin{array}{l}\text { Mix of } \\
\text { retrospective and } \\
\text { prospective }\end{array}$ & $\begin{array}{l}\text { Health care workers were } \\
\text { interviewed over a period } \\
\text { of one year. }\end{array}$ & $\begin{array}{l}13 \% \text { reported accidental injuries with } \\
\text { HIV-positive patients. The highest } \\
\text { frequencies of injuries were among } \\
\text { registrars. Compliance with universal } \\
\text { precautions was suboptimal. } 48 \% \text { of the } \\
\text { participants on post-exposure prophylaxis } \\
\text { (PEP) did not complete their regimen; the } \\
\text { side effects of PEP was reported as the main } \\
\text { reason for discontinuation. }\end{array}$ \\
\hline
\end{tabular}


Table 1. Cont.

\begin{tabular}{|c|c|c|c|c|c|c|c|}
\hline Authors & Year & Topic & Origin & Participants & Type of Study & Methods & Findings \\
\hline $\begin{array}{l}\text { Phipps et al. } \\
{[33]}\end{array}$ & 2002 & $\begin{array}{l}\text { Needlestick injuries; } \\
\text { and knowledge, } \\
\text { attitudes and } \\
\text { practices }\end{array}$ & China & $\begin{array}{l}441 \text { nurses working } \\
\text { in } 3 \text { tertiary care } \\
\text { hospitals in Hunan } \\
\text { Province }\end{array}$ & Cross-sectional & $\begin{array}{l}\text { Questionnaire on } \\
\text { needlestick injuries in } \\
\text { the past year, Hepatitis B } \\
\text { knowledge and } \\
\text { immunization status, } \\
\text { and work practices. }\end{array}$ & $\begin{array}{l}82 \% \text { of the nurses reported experiencing a } \\
\text { needlestick injury in the past year. These } \\
\text { injuries occurred most frequently when } \\
\text { separating a needle and syringe, } \\
\text { recapping a needle, transporting needles } \\
\text { for disposal, and giving injections. Only } \\
8 \% \text { reported the injuries to an authority. } \\
\text { The majority never wore gloves when } \\
\text { drawing blood, giving an injection or } \\
\text { starting an intravenous line. } 29 \% \text { were } \\
\text { not vaccinated against Hepatitis B. }\end{array}$ \\
\hline $\begin{array}{c}\text { Talaat et al. } \\
\text { [34] }\end{array}$ & 2003 & $\begin{array}{l}\text { Needlestick injuries } \\
\text { and Hepatitis B } \\
\text { vaccination status }\end{array}$ & Egypt & $\begin{array}{l}1485 \text { health care } \\
\text { workers from health } \\
\text { facilities in } 2 \\
\text { governorates (Nile } \\
\text { Delta and Upper } \\
\text { Egypt) }\end{array}$ & Cross-sectional & $\begin{array}{l}\text { Questionnaire on } \\
\text { needlestick injuries and } \\
\text { Hepatitis B vaccination } \\
\text { status. }\end{array}$ & $\begin{array}{l}36.6 \% \text { reported at least one needlestick } \\
\text { injury in the past } 3 \text { months. Two-hand } \\
\text { recapping was the most common } \\
\text { behaviour associated with needlestick } \\
\text { injury. } 15.8 \% \text { reported being fully } \\
\text { vaccinated against Hepatitis B; } \\
\text { vaccination rates were lowest among } \\
\text { housekeeping personnel. }\end{array}$ \\
\hline $\begin{array}{l}\text { Kermode et al. } \\
\text { [35] }\end{array}$ & 2005 & Needlestick injuries & India & $\begin{array}{l}266 \text { health care } \\
\text { workers from } 7 \text { rural } \\
\text { health settings } \\
\text { (hospitals with } \\
\text { attached community } \\
\text { health projects) in } \\
\text { north India }\end{array}$ & Cross-sectional & $\begin{array}{l}\text { Questionnaire on } \\
\text { needlestick or sharps } \\
\text { injuries in the past week, } \\
\text { past year, and over the } \\
\text { working lifetime. }\end{array}$ & $\begin{array}{l}63 \% \text { reported at least } 1 \text { needlestick injury } \\
\text { in the last year and } 73 \% \text { over their } \\
\text { working lifetime. Doctors and nurses } \\
\text { were more likely to be exposed than } \\
\text { student nurses and laboratory workers. }\end{array}$ \\
\hline $\begin{array}{l}\text { Kermode et al. } \\
\text { [36] }\end{array}$ & 2005 & $\begin{array}{c}\text { Compliance with } \\
\text { universal precautions } \\
\text { (UP) }\end{array}$ & India & $\begin{array}{l}266 \text { health care } \\
\text { workers from } 7 \text { rural } \\
\text { health settings } \\
\text { (hospitals with } \\
\text { attached community } \\
\text { health projects) in } \\
\text { north India }\end{array}$ & Cross-sectional & $\begin{array}{l}\text { Questionnaire on } 12 \\
\text { behaviours related to the } \\
\text { practice of UP. }\end{array}$ & $\begin{array}{l}\text { Compliance with UP was not optimal. } \\
\text { Compliance with UP was associated with } \\
\text { being in the job for a longer period, } \\
\text { knowledge of bloodborne pathogen } \\
\text { transmission, perceiving fewer barriers to } \\
\text { safe practice and strong commitment to } \\
\text { workplace safety climate. }\end{array}$ \\
\hline
\end{tabular}


Table 1. Cont.

\begin{tabular}{|c|c|c|c|c|c|c|c|}
\hline Authors & Year & Topic & Origin & Participants & Type of Study & Methods & Findings \\
\hline $\begin{array}{c}\text { Nsubuga and } \\
\text { Jaakkola [37] }\end{array}$ & 2005 & $\begin{array}{l}\text { Needlestick and } \\
\text { sharps injuries and } \\
\text { risk factors }\end{array}$ & Uganda & $\begin{array}{l}526 \text { midwives } \\
\text { and nurses in a } \\
\text { tertiary care } \\
\text { hospital in } \\
\text { Kampala }\end{array}$ & Cross-sectional & $\begin{array}{l}\text { Questionnaire on } \\
\text { needlestick injuries and } \\
\text { risk factors. }\end{array}$ & $\begin{array}{l}57 \% \text { reported a needlestick injury in the } \\
\text { last year and } 82 \% \text { in their entire career. } \\
\text { The risk factors identified were lack of } \\
\text { training, working for more than } \\
40 \mathrm{~h} / \text { week, recapping needles, and not } \\
\text { using gloves when handling needles. } \\
\text { Lack of training was the strongest } \\
\text { predictor. }\end{array}$ \\
\hline Obi et al. [38] & 2005 & $\begin{array}{l}\text { Needlestick injuries } \\
\text { and splashes, and } \\
\text { use of personal } \\
\text { protective equipment } \\
\text { (PPE) }\end{array}$ & Nigeria & $\begin{array}{l}264 \text { surgeons } \\
\text { from five tertiary } \\
\text { health } \\
\text { institutions in } \\
\text { Southeast Nigeria }\end{array}$ & Cross-sectional & $\begin{array}{l}\text { Questionnaire on } \\
\text { needlestick injuries and } \\
\text { splashes in the last } 5 \text { years, } \\
\text { use of PPE, and attitudes } \\
\text { towards care of } \\
\text { HIV-infected patients. }\end{array}$ & $\begin{array}{l}40.2 \% \text { reported a needlestick injury and } \\
26 \% \text { reported blood splashes in the past } \\
\text { five years. The highest frequencies were } \\
\text { reported in resident surgeons. All wore } \\
\text { protective aprons, } 65.2 \% \text { used double } \\
\text { gloves and } 30.3 \% \text { used goggles during } \\
\text { surgical procedures. } 83 \% \text { had some } \\
\text { reservations about treating HIV-positive } \\
\text { patients. }\end{array}$ \\
\hline $\begin{array}{l}\text { Akinleye and } \\
\text { Omokhodion } \\
{[40]}\end{array}$ & 2008 & $\begin{array}{l}\text { Needlestick injuries } \\
\text { and work practices }\end{array}$ & Nigeria & $\begin{array}{l}270 \text { primary } \\
\text { health care } \\
\text { workers from two } \\
\text { urban and three } \\
\text { rural local } \\
\text { government areas }\end{array}$ & Cross-sectional & $\begin{array}{l}\text { Questionnaire on } \\
\text { needlestick injuries in the } \\
\text { past year and work } \\
\text { practices. }\end{array}$ & $\begin{array}{l}32 \% \text { reported a needlestick injury in the } \\
\text { past year. Compliance with the use of } \\
\text { gloves and hand washing were greater } \\
\text { among rural than urban health workers. }\end{array}$ \\
\hline $\begin{array}{c}\text { Okeke et al. } \\
\text { [41] }\end{array}$ & 2008 & $\begin{array}{l}\text { Needlestick injuries } \\
\text { and Hepatitis B } \\
\text { vaccination status }\end{array}$ & Nigeria & $\begin{array}{l}346 \text { medical } \\
\text { students in a } \\
\text { tertiary institute }\end{array}$ & Cross-sectional & $\begin{array}{l}\text { Questionnaire on } \\
\text { needlestick injuries and } \\
\text { splashes, and Hepatitis B } \\
\text { vaccination status }\end{array}$ & $\begin{array}{l}48 \% \text { reported a previous needlestick } \\
\text { injury and } 27.7 \% \text { reported being } \\
\text { vaccinated against Hepatitis B. }\end{array}$ \\
\hline
\end{tabular}


Table 1. Cont.

\begin{tabular}{|c|c|c|c|c|c|c|c|}
\hline Authors & Year & Topic & Origin & Participants & Type of Study & Methods & Findings \\
\hline $\begin{array}{c}\text { Taegtmeyer } \\
\text { et al. [42] }\end{array}$ & 2008 & $\begin{array}{l}\text { Needlestick injuries } \\
\text { (NSIs) and safety } \\
\text { practices }\end{array}$ & Kenya & $\begin{array}{l}650 \text { health care } \\
\text { workers from } \\
11 \text { health facilities in } \\
\text { Thika District }\end{array}$ & Prospective & $\begin{array}{l}\text { Questionnaires and } \\
\text { semi-structured interviews; } \\
\text { together with an } \\
\text { intervention of } \\
\text { introduction of biosafety } \\
\text { measures, vaccination, and } \\
\text { post-exposure prophylaxis } \\
\text { (PEP). Surveys were } \\
\text { conducted at baseline and } \\
\text { at one year. }\end{array}$ & $\begin{array}{l}\text { The incidence of NSIs was } 0.97 \text { per health } \\
\text { care worker per year. After the institution } \\
\text { of biosafety measures, there was a } \\
\text { significant reduction in injuries, an } \\
\text { increase in the health care workers } \\
\text { accessing HIV testing and in the uptake } \\
\text { of Hepatitis B vaccination uptake, but the } \\
\text { uptake of PEP was low. }\end{array}$ \\
\hline $\begin{array}{c}\text { Chen et al. } \\
\text { [43] }\end{array}$ & 2009 & $\begin{array}{l}\text { Sharp object } \\
\text { injuries }\end{array}$ & China & $\begin{array}{l}831 \text { health care } \\
\text { workers from } \\
9 \text { hospitals in Fujian, } \\
\text { who worked in } \\
\text { departments with a } \\
\text { high risk of } \\
\text { occupational } \\
\text { exposures to blood }\end{array}$ & Cross-sectional & $\begin{array}{l}\text { Questionnaire on sharp } \\
\text { object injuries in the past } \\
\text { year. }\end{array}$ & $\begin{array}{l}86.2 \% \text { of the health care workers reported } \\
\text { a sharps injury on the job and } 71.3 \% \text { said } \\
\text { that it had occurred in the past year. } \\
\text { Nurses reported the highest frequencies } \\
\text { of injuries, followed by surgeons, } \\
\text { anaesthetists, and laboratory workers. } \\
\text { Disposable syringes caused most of the } \\
\text { injuries. }\end{array}$ \\
\hline Simon [44] & 2009 & Needlestick injuries & India & $\begin{array}{l}50 \text { nurses in a } \\
\text { super-speciality } \\
\text { tertiary care hospital } \\
\text { in Delhi }\end{array}$ & Cross-sectional & $\begin{array}{l}\text { Questionnaire on } \\
\text { needlestick injuries, and } \\
\text { knowledge and practices } \\
\text { on needlestick injuries. }\end{array}$ & $\begin{array}{l}70 \% \text { had sustained a needlestick injury } \\
\text { during their career, and of these the } \\
\text { majority }(71 \%) \text { did not report it. There } \\
\text { was a lack of awareness on prevention } \\
\text { and management of NSIs. }\end{array}$ \\
\hline $\begin{array}{c}\text { Chakravarthy } \\
\text { et al. [45] }\end{array}$ & 2010 & $\begin{array}{l}\text { Sharps injuries, and } \\
\text { blood and body } \\
\text { fluid exposure } \\
\text { incidents }\end{array}$ & India & $\begin{array}{l}265 \text { health care } \\
\text { workers who } \\
\text { reported sharps } \\
\text { injuries and } \\
\text { accidental blood and } \\
\text { body fluid exposures } \\
\text { to the Infection } \\
\text { Control Committee } \\
\text { of } 4 \text { tertiary referral } \\
\text { hospitals }\end{array}$ & $\begin{array}{l}\text { Retrospective } \\
\text { review of data } \\
\text { from sharp injury, } \\
\text { and blood and } \\
\text { body fluid } \\
\text { exposure reports }\end{array}$ & $\begin{array}{l}\text { Data were obtained from } \\
\text { sharps injuries, and blood } \\
\text { and body fluid exposures } \\
\text { reports that were reported } \\
\text { to the Infection Control } \\
\text { Committees of the } \\
4 \text { hospitals. Data collection } \\
\text { period ranged from } 6 \text { to } \\
26 \text { months. }\end{array}$ & $\begin{array}{l}243 \text { sharps injuries and } 22 \text { incidents of } \\
\text { blood and body fluids exposures were } \\
\text { reported in the cumulated } 50 \text { months of } \\
\text { study. The highest frequencies of injuries } \\
\text { were reported by nurses and } \\
\text { housekeeping staff. The majority of the } \\
\text { injuries were caused by disposable } \\
\text { needles. }\end{array}$ \\
\hline
\end{tabular}


Table 1. Cont.

\begin{tabular}{|c|c|c|c|c|c|c|c|}
\hline Authors & Year & Topic & Origin & Participants & Type of Study & Methods & Findings \\
\hline $\begin{array}{l}\text { Yacoub et al. } \\
{[46]}\end{array}$ & 2010 & $\begin{array}{l}\text { Needlestick injuries } \\
\text { and Hepatitis B } \\
\text { vaccination status }\end{array}$ & Syria & $\begin{array}{l}321 \text { health care } \\
\text { workers from } \\
\text { three tertiary care } \\
\text { hospitals in } \\
\text { Aleppo }\end{array}$ & Cross-sectional & $\begin{array}{l}\text { Questionnaire on } \\
\text { needlestick injuries and } \\
\text { Hepatitis B vaccination } \\
\text { status. Blood was collected } \\
\text { to test for Hepatitis B } \\
\text { (HBsAg). }\end{array}$ & $\begin{array}{l}76.6 \% \text { reported at least one needlestick } \\
\text { injury in the past year. Anaesthesiology } \\
\text { technicians, doctors, nurses, and } \\
\text { housekeeping had the greatest exposure } \\
\text { risks. } 56.1 \% \text { reported being fully } \\
\text { vaccinated against Hepatitis B; } \\
\text { vaccination rates were lowest among } \\
\text { housekeeping personnel. } 2.8 \% \text { tested } \\
\text { positive for HBsAg. }\end{array}$ \\
\hline $\begin{array}{c}\text { Sangwan et al. } \\
{[47]}\end{array}$ & 2011 & $\begin{array}{l}\text { Needlestick injuries } \\
\text { and splashes }\end{array}$ & India & $\begin{array}{l}70 \text { health care } \\
\text { workers in a } \\
\text { tertiary care } \\
\text { hospital }\end{array}$ & Cross-sectional & $\begin{array}{l}\text { Questionnaire on } \\
\text { needlestick injuries and } \\
\text { splashes in the past year, } \\
\text { and reasons for not using } \\
\text { PPE. }\end{array}$ & $\begin{array}{l}71.43 \% \text { reported a needlestick injury in } \\
\text { the past year. The most frequent reasons } \\
\text { for not using PPE were in emergencies } \\
\text { and other co-workers not using them. } \\
\text { Only } 34 \% \text { reported that adequate PPE } \\
\text { was always provided. }\end{array}$ \\
\hline Irmak [48] & 2012 & $\begin{array}{l}\text { Needlestick and } \\
\text { sharps injuries }\end{array}$ & Turkey & $\begin{array}{l}143 \text { nurses } \\
\text { working patient } \\
\text { care in a state } \\
\text { hospital }\end{array}$ & Cross-sectional & $\begin{array}{l}\text { Questionnaire on } \\
\text { needlestick and sharps } \\
\text { injuries in the past year. }\end{array}$ & $\begin{array}{l}30.1 \% \text { of the nurses reported at least one } \\
\text { sharp object injury in the past year. The } \\
\text { use of syringe needles was the most } \\
\text { common cause of injury. } 16.3 \% \text { of the } \\
\text { nurses were not wearing gloves when } \\
\text { they sustained the injury. }\end{array}$ \\
\hline $\begin{array}{l}\text { Nasim et al. } \\
\text { [49] }\end{array}$ & 2012 & $\begin{array}{l}\text { Safe work practices } \\
\text { and use of personal } \\
\text { protective equipment }\end{array}$ & Pakistan & $\begin{array}{l}\text { 1782 laboratory } \\
\text { technicians from } \\
\text { public sector } \\
\text { hospitals and } \\
\text { private hospital } \\
\text { laboratories } \\
\text { throughout } \\
\text { Pakistan }\end{array}$ & Cross-sectional & $\begin{array}{l}\text { Questionnaire on safe and } \\
\text { unsafe work practices, and } \\
\text { the use of personal } \\
\text { protective equipment. }\end{array}$ & $\begin{array}{l}31.9 \% \text { did not use any kind of personal } \\
\text { protective equipment, } 46 \% \text { reported } \\
\text { reusing syringes, } 43.2 \% \text { regularly } \\
\text { recapped needles after use, } 67.2 \% \text { said } \\
\text { that standard operating procedures were } \\
\text { not available, and } 84.2 \% \text { had no formal } \\
\text { biosafety training. }\end{array}$ \\
\hline $\begin{array}{l}\text { Omorogbe } \\
\text { et al. [50] }\end{array}$ & 2012 & $\begin{array}{l}\text { Injection safety } \\
\text { practices and use of } \\
\text { PPE }\end{array}$ & Nigeria & $\begin{array}{l}122 \text { nurses from } \\
6 \text { mission } \\
\text { hospitals in Benin } \\
\text { city }\end{array}$ & Cross-sectional & $\begin{array}{l}\text { Questionnaire adapted } \\
\text { from the WHO injection } \\
\text { safety assessment tool and } \\
\text { observation of practices. }\end{array}$ & $\begin{array}{l}55.8 \% \text { reported recapping of needles and } \\
\text { only } 3.3 \% \text { said that they regularly used } \\
\text { gloves when giving injections. }\end{array}$ \\
\hline
\end{tabular}


Table 1. Cont.

\begin{tabular}{|c|c|c|c|c|c|c|c|}
\hline Authors & Year & Topic & Origin & Participants & Type of Study & Methods & Findings \\
\hline $\begin{array}{l}\text { Phillips et al. } \\
\text { [51] }\end{array}$ & 2012 & $\begin{array}{l}\text { Needlestick and } \\
\text { sharps injuries }\end{array}$ & Zambia & $\begin{array}{l}442 \text { health care } \\
\text { workers from five } \\
\text { health facilities in } \\
\text { Lusaka and } \\
\text { Livingstone }\end{array}$ & Cross-sectional & $\begin{array}{l}\text { Questionnaire on } \\
\text { needlestick and sharps } \\
\text { injuries in the past year. }\end{array}$ & $\begin{array}{l}\text { The annual average sharps injury rate } \\
\text { was } 1.3 \text { injuries/worker. The highest } \\
\text { frequencies were reported by nurses and } \\
\text { service workers. Syringe needles } \\
\text { accounted for the majority of the injuries. } \\
88 \% \text { reported the availability of PPE, but } \\
\text { only } 8 \% \text { were fully vaccinated against } \\
\text { Hepatitis B. }\end{array}$ \\
\hline $\begin{array}{c}\text { Sethi et al. } \\
\text { [52] }\end{array}$ & 2012 & $\begin{array}{l}\text { Compliance with } \\
\text { infection control } \\
\text { practices }\end{array}$ & Uganda & $\begin{array}{l}183 \text { health care } \\
\text { workers from a } \\
\text { referral hospital } \\
\text { in Kampala }\end{array}$ & Cross-sectional & $\begin{array}{l}\text { Questionnaire on hand } \\
\text { hygiene, barrier protection, } \\
\text { and contact precautions. }\end{array}$ & $\begin{array}{l}68.9 \% \text { reported using gloves as barrier } \\
\text { protection. Universal precautions were } \\
\text { not always followed. The reasons for } \\
\text { suboptimal infection control practices } \\
\text { were lack of time and lack of resources. }\end{array}$ \\
\hline $\begin{array}{c}\text { Abkar et al. } \\
\text { [53] }\end{array}$ & 2013 & $\begin{array}{l}\text { Unsafe injection } \\
\text { practices }\end{array}$ & Yemen & $\begin{array}{l}127 \text { health care } \\
\text { workers from two } \\
\text { hospitals and } \\
6 \text { rural health } \\
\text { centres }\end{array}$ & Cross-sectional & $\begin{array}{l}\text { Questionnaire and } \\
\text { observation of injection } \\
\text { practices. }\end{array}$ & $\begin{array}{l}\text { There were several unsafe practices, } \\
\text { particularly the recapping of needles after } \\
\text { use, which occurred in } 61.1 \% \text { and } 36.8 \% \\
\text { of the observations in the hospitals and } \\
\text { health centres, respectively. }\end{array}$ \\
\hline $\begin{array}{l}\text { Afridi et al. } \\
\text { [54] }\end{array}$ & 2013 & $\begin{array}{l}\text { Needlestick injuries, } \\
\text { Hepatitis B } \\
\text { vaccination status } \\
\text { and infection control } \\
\text { measures }\end{array}$ & Pakistan & $\begin{array}{l}497 \text { health care } \\
\text { workers from two } \\
\text { tertiary care } \\
\text { hospitals in } \\
\text { Karachi }\end{array}$ & Cross-sectional & $\begin{array}{l}\text { Questionnaire on } \\
\text { needlestick injuries, } \\
\text { Hepatitis B vaccination } \\
\text { status and infection control } \\
\text { measures. }\end{array}$ & $\begin{array}{l}64 \% \text { reported needlestick injuries during } \\
\text { their career. Working for more than } \\
5 \text { years and working as a nurse were the } \\
\text { factors associated with an increased risks. } \\
\text { Injecting medicine, drawing blood, and } \\
\text { two hand recapping of needles were the } \\
\text { practices associated with needlestick } \\
\text { injuries. } 34 \% \text { reported being vaccinated } \\
\text { against Hepatitis B. Infection control } \\
\text { measures were inadequate. }\end{array}$ \\
\hline
\end{tabular}


Table 1. Cont.

\begin{tabular}{|c|c|c|c|c|c|c|c|}
\hline Authors & Year & Topic & Origin & Participants & Type of Study & Methods & Findings \\
\hline $\begin{array}{l}\text { Rajkumari } \\
\text { et al. [55] }\end{array}$ & 2014 & $\begin{array}{l}\text { Needlestick injuries } \\
\text { and splashes }\end{array}$ & India & $\begin{array}{l}356 \text { health care } \\
\text { workers who } \\
\text { reported sharps } \\
\text { injuries and } \\
\text { splashes in a } \\
\text { tertiary hospital } \\
\text { in New Delhi }\end{array}$ & Prospective & $\begin{array}{l}\text { Surveillance of sharps } \\
\text { injuries over a } 2 \text { years } \\
5 \text { months period. Health } \\
\text { care workers who reported } \\
\text { sharps injuries during this } \\
\text { period completed a } \\
\text { questionnaire. Blood } \\
\text { samples were collected at } \\
\text { baseline and } 6 \text { months } \\
\text { later to be tested for } \\
\text { Hepatitis B, C and HIV. }\end{array}$ & $\begin{array}{l}\text { Highest frequencies of sharps injuries } \\
\text { were reported by doctors ( } 36.2 \%) \text {, } \\
\text { followed by nurses }(14.6 \%) \text { and hospital } \\
\text { waste disposal staff }(7.6 \%) \text {. There was no } \\
\text { seroconversion among the exposed health } \\
\text { care workers. The majority ( } 85.1 \% \text { ) of the } \\
\text { injuries reported were from sharps (as } \\
\text { compared to splashes). Only } 55.3 \% \text { were } \\
\text { using PPE during the time of exposure. }\end{array}$ \\
\hline $\begin{array}{l}\text { Bekele et al. } \\
\text { [56] }\end{array}$ & 2015 & $\begin{array}{l}\text { Needlestick injury } \\
\text { reporting and } \\
\text { attitudes }\end{array}$ & Ethiopia & $\begin{array}{l}340 \text { health care } \\
\text { workers from } \\
\text { four hospitals of } \\
\text { Bale zone }\end{array}$ & Cross-sectional & $\begin{array}{l}\text { Questionnaire on } \\
\text { needlestick injury } \\
\text { reporting and attitudes. }\end{array}$ & $\begin{array}{l}98.2 \% \text { were aware of the risks of } \\
\text { needlestick injuries. } 58.7 \% \text { of needlestick } \\
\text { injuries were not reported. The main } \\
\text { reasons for not reporting were time } \\
\text { constraints, sharps that caused the injury } \\
\text { were not used by patients, the source } \\
\text { patient did not have diseases of concern, } \\
\text { and lack of knowledge of reporting. }\end{array}$ \\
\hline $\begin{array}{l}\text { Priya et al. } \\
\text { [57] }\end{array}$ & 2015 & $\begin{array}{l}\text { Needlestick injuries } \\
\text { and splashes }\end{array}$ & India & $\begin{array}{l}105 \text { health care } \\
\text { workers who } \\
\text { reported sharps } \\
\text { injuries and } \\
\text { accidental blood } \\
\text { and body fluid } \\
\text { exposures to the } \\
\text { anti-retroviral } \\
\text { therapy centre of } \\
\text { a tertiary care } \\
\text { hospital }\end{array}$ & $\begin{array}{l}\text { Retrospective } \\
\text { review of data } \\
\text { from sharp injury, } \\
\text { and blood and } \\
\text { body fluid } \\
\text { exposure reports }\end{array}$ & $\begin{array}{l}\text { Data from three years were } \\
\text { obtained from sharps } \\
\text { injuries, and blood and } \\
\text { body fluid exposures } \\
\text { reports that were reported } \\
\text { to the Anti-retroviral } \\
\text { therapy centre of a tertiary } \\
\text { care hospital. }\end{array}$ & $\begin{array}{l}105 \text { health care workers reported an } \\
\text { occupational exposure to blood and body } \\
\text { fluids. The highest frequencies were } \\
\text { reported by interns. Needlestick injuries } \\
\text { were the commonest type of exposure } \\
(85 \%) \text {, followed by mucous membrane } \\
\text { splash }(13 \%) \text { and exposure on intact skin } \\
(2 \%) \text {. The practices that resulted in } \\
\text { exposures were blood withdrawal } \\
(45.7 \%) \text {, during surgical procedures } \\
(24.7 \%) \text { and disposal of sharps }(23 \%) \text {. }\end{array}$ \\
\hline
\end{tabular}


Table 1. Cont.

\begin{tabular}{|c|c|c|c|c|c|c|c|}
\hline Authors & Year & Topic & Origin & Participants & Type of Study & Methods & Findings \\
\hline $\begin{array}{l}\text { Sabermoghaddam } \\
\text { et al. [58] }\end{array}$ & 2015 & $\begin{array}{l}\text { Needlestick } \\
\text { injuries and } \\
\text { splashes }\end{array}$ & Iran & $\begin{array}{l}371 \text { health care } \\
\text { workers from } \\
6 \text { government } \\
\text { hospitals in the } \\
\text { Northern } \\
\text { Khorasan } \\
\text { province }\end{array}$ & Cross-sectional & $\begin{array}{l}\text { Questionnaire on } \\
\text { needlestick injuries and } \\
\text { splashes in the past year. }\end{array}$ & $\begin{array}{l}44 \% \text { reported a sharp object injury and } 31 \% \text { reported } \\
\text { contact with blood and body fluids in the past year. } \\
91 \% \text { reported always using a safety box to deposit } \\
\text { used needles, } 35.9 \% \text { reported washing their hands } \\
\text { before and after examining patients, } 41.5 \% \text { reported } \\
\text { using gloves, } 58 \% \text { had attended training on safe } \\
\text { handling of sharps. } 52 \% \text { of those who were injured } \\
\text { did not report the injury. }\end{array}$ \\
\hline $\begin{array}{l}\text { Türe et al. } \\
\text { [59] }\end{array}$ & 2016 & $\begin{array}{c}\text { Needlestick } \\
\text { injuries and } \\
\text { splashes, and risk } \\
\text { factors }\end{array}$ & Turkey & $\begin{array}{l}166 \text { health care } \\
\text { workers who } \\
\text { reported sharps } \\
\text { injuries and } \\
\text { accidental blood } \\
\text { and body fluid } \\
\text { exposures to the } \\
\text { Infection Control } \\
\text { Committee of a } \\
\text { tertiary care } \\
\text { hospital }\end{array}$ & $\begin{array}{l}\text { Retrospective } \\
\text { review of data } \\
\text { from sharp } \\
\text { injuries, and } \\
\text { blood and body } \\
\text { fluid exposure } \\
\text { reports }\end{array}$ & $\begin{array}{l}\text { Data were obtained from } \\
\text { sharps injuries, and blood } \\
\text { and body fluid exposure } \\
\text { reports that were reported } \\
\text { to the Infection Control } \\
\text { Committee. Data } \\
\text { collection period was from } \\
\text { August } 2011 \text { to June } 2013 \text {. }\end{array}$ & $\begin{array}{l}166 \text { health care workers reported an occupational } \\
\text { exposure to blood and body fluids. The occupational } \\
\text { exposure incidence was } 2.18 \text { exposures / person-year. } \\
\text { The highest frequencies of injuries were reported by } \\
\text { nurses and cleaning staff. Having heavy workloads } \\
\text { and long working hours increased the risk of } \\
\text { exposures whereas increased work experience } \\
\text { decreased the risk of exposures. }\end{array}$ \\
\hline $\begin{array}{l}\text { Konlan et al. } \\
{[60]}\end{array}$ & 2017 & $\begin{array}{l}\text { Hepatitis B } \\
\text { vaccination status } \\
\text { and practices to } \\
\text { reduce } \\
\text { occupational } \\
\text { exposures }\end{array}$ & Ghana & $\begin{array}{l}108 \text { nurses from } \\
\text { two hospitals } \\
\text { within the Tamale } \\
\text { metropolis }\end{array}$ & Cross-sectional & $\begin{array}{l}\text { Questionnaire on Hepatitis } \\
\text { B vaccination status and } \\
\text { practices to reduce } \\
\text { occupational exposures to } \\
\text { Hepatitis B. }\end{array}$ & $\begin{array}{l}64.8 \% \text { said that they reported occupational exposures } \\
\text { to Hepatitis B. } 33.3 \% \text { reported receiving } 3 \text { doses of } \\
\text { Hepatitis B vaccination. Compliance with } \\
\text { precautions to reduce occupational exposures was } \\
\text { suboptimal. }\end{array}$ \\
\hline $\begin{array}{l}\text { Matsubara } \\
\text { et al. [61] }\end{array}$ & 2017 & $\begin{array}{l}\text { Needlestick and } \\
\text { sharps injuries } \\
\text { and risk factors }\end{array}$ & Lao PDR & $\begin{array}{l}623 \text { health care } \\
\text { workers from } \\
4 \text { tertiary care } \\
\text { hospitals in } \\
\text { Vientiane Capital }\end{array}$ & Cross-sectional & $\begin{array}{l}\text { Questionnaire on } \\
\text { needlestick injuries over } \\
\text { their entire career, and in } \\
\text { the past } 6 \text { months, and } \\
\text { injection practices based } \\
\text { on the World Health } \\
\text { Organization } \\
\text { questionnaire on injection } \\
\text { practices. }\end{array}$ & $\begin{array}{l}11.4 \% \text { reported a needlestick injury in the past } \\
6 \text { months and } 42.1 \% \text { in their entire career. The } \\
\text { highest frequencies were reported by surgeons, } \\
\text { dentists and cleaners. The injuries were caused by } \\
\text { percutaneous injections }(17.9 \%) \text {, suturing needles } \\
(17.0 \%) \text {, intravenous line insertion }(17.0 \%) \text {, recapping } \\
\text { needles }(13.2 \%) \text {, disposal }(10.4 \%) \text {, and others ( } 24.5 \%) \text {. } \\
\text { Protective factors for needlestick injuries identified } \\
\text { were adequate availability of needles and syringes, } \\
\text { and adequate training. }\end{array}$ \\
\hline
\end{tabular}


Table 1. Cont

\begin{tabular}{|c|c|c|c|c|c|c|c|}
\hline Authors & Year & Topic & Origin & Participants & Type of Study & Methods & Findings \\
\hline $\begin{array}{l}\text { Geberemariyam } \\
\text { et al. [62] }\end{array}$ & 2018 & $\begin{array}{c}\text { Needlestick } \\
\text { injures and } \\
\text { infection control } \\
\text { practices }\end{array}$ & Ethiopia & $\begin{array}{l}648 \text { health care } \\
\text { workers with } \\
\text { direct } \\
\text { involvement in } \\
\text { patient care in } \\
\text { public health care } \\
\text { facilities in one } \\
\text { district }\end{array}$ & Cross-sectional & $\begin{array}{l}\text { Questionnaire on needlestick } \\
\text { injuries and infection control } \\
\text { practices. }\end{array}$ & $\begin{array}{l}\text { Only } 36.3 \% \text { reported safe infection prevention } \\
\text { practices. Life-time prevalence of needlesticks } \\
\text { and blood or body fluid exposure } 32.4 \% \text { and } \\
39.0 \% \text {, respectively, with } 24.8 \% \text { of them having } \\
>1 \text { injuries. Exposures occurred mostly during } \\
\text { intravenous catheter insertion, suturing, and } \\
\text { recapping of needles. Factors associated with } \\
\text { better infection control practices were profession, } \\
\text { service years, presence of infection prevention } \\
\text { committee and guideline, and ever taking } \\
\text { training. }\end{array}$ \\
\hline $\begin{array}{c}\text { Mandić et al. } \\
{[63]}\end{array}$ & 2018 & $\begin{array}{l}\text { Needlestick } \\
\text { injuries and } \\
\text { splashes }\end{array}$ & Serbia & $\begin{array}{l}5247 \text { health care } \\
\text { workers who } \\
\text { routinely worked } \\
\text { with blood from } \\
17 \text { general } \\
\text { hospitals in } \\
\text { Serbia }\end{array}$ & Cross-sectional & $\begin{array}{l}\text { Questionnaire on needlestick } \\
\text { injuries and splashes over } \\
\text { their entire career and in the } \\
\text { last year. }\end{array}$ & $\begin{array}{l}39 \% \text { reported an exposure to blood and body } \\
\text { fluids in the past year and } 66 \% \text { over their entire } \\
\text { career. The prevalence of needlestick injuries } \\
\text { occurring in the last year was equal among } \\
\text { genders, but it was more prevalent in women } \\
\text { during the entire career. The highest frequencies } \\
\text { were reported in nurses. }\end{array}$ \\
\hline $\begin{array}{l}\text { Hebo et al. } \\
\text { [64] }\end{array}$ & 2019 & $\begin{array}{l}\text { Exposure to } \\
\text { blood and body } \\
\text { fluids, practices } \\
\text { of standard } \\
\text { precautions and } \\
\text { seroprevalance of } \\
\text { Hepatitis B and C }\end{array}$ & Ethiopia & $\begin{array}{l}240 \text { health care } \\
\text { workers from } \\
\text { Jimma University } \\
\text { Medical Center }\end{array}$ & Cross-sectional & $\begin{array}{l}\text { Questionnaires on exposure } \\
\text { to blood and body fluids and } \\
\text { use of standard precautions. } \\
\text { Blood was collected and } \\
\text { tested for Hepatitis B and C. }\end{array}$ & $\begin{array}{l}60 \% \text { reported being ever exposed and } 43 \% \\
\text { reported exposure in the past year to blood and } \\
\text { body fluids through accidental splashes and } \\
\text { sharps injuries. } 2.5 \% \text { of the samples was positive } \\
\text { for HBsAg and } 0.42 \% \text { for anti-HCV antibodies. } \\
\text { Only } 42.6 \% \text { had good practices of standard } \\
\text { precautions. }\end{array}$ \\
\hline \multicolumn{8}{|c|}{ II. Tuberculosis (TB) } \\
\hline Lien et al. [65] & 2009 & $\begin{array}{l}\text { Prevalence of } \\
\text { latent TB and risk } \\
\text { factors }\end{array}$ & Vietnam & $\begin{array}{l}150 \text { health care } \\
\text { workers from a } \\
\text { TB hospital and } \\
150 \text { from a } \\
\text { non-TB hospital } \\
\text { in Hanoi }\end{array}$ & Cross-sectional & $\begin{array}{l}\text { Questionnaire on } \\
\text { occupational history; } \\
\text { interferon-gamma release } \\
\text { assay (IGRA), } \\
\text { QuantiFERON-TB Gold } \\
\text { In-Tube assay and one- and } \\
\text { two-step tuberculin skin } \\
\text { tests (TSTs) for TB infection. }\end{array}$ & $\begin{array}{l}\text { Prevalence of TB infection was } 47.3 \%, 61.1 \% \text { and } \\
66.3 \% \text { as estimated by IGRA, one- and two-step } \\
\text { TST, respectively. Working in a TB hospital, } \\
\text { increasing age, lower education levels, and } \\
\text { higher body mass index were associated with } \\
\text { increased risk of IGRA positivity. }\end{array}$ \\
\hline
\end{tabular}


Table 1. Cont.

\begin{tabular}{|c|c|c|c|c|c|c|c|}
\hline Authors & Year & Topic & Origin & Participants & Type of Study & Methods & Findings \\
\hline $\begin{array}{l}\text { Mathew et al. } \\
\text { [66] }\end{array}$ & 2013 & $\begin{array}{l}\text { TB among health } \\
\text { care workers }\end{array}$ & India & $\begin{array}{l}101 \text { health care } \\
\text { workers with TB } \\
\text { (cases) and } 101 \\
\text { without TB in a } \\
\text { tertiary care } \\
\text { hospital in } \\
\text { Vellore }\end{array}$ & $\begin{array}{c}\text { Nested } \\
\text { case-control }\end{array}$ & $\begin{array}{l}\text { Questionnaire on } \\
\text { occupational history and } \\
\text { non-occupational exposure } \\
\text { to TB. }\end{array}$ & $\begin{array}{l}\text { Rate of active pulmonary TB was } 314 \text { per } \\
100,000 \text { person-years, which was } 1.86 \text { times higher } \\
\text { than that of the general population. Body mass } \\
\text { index }<19 \mathrm{~kg} / \mathrm{m}^{2} \text {, having frequent contact with } \\
\text { patients, and working in the medical wards or } \\
\text { microbiology laboratories were independently } \\
\text { associated with increased risk of TB }\end{array}$ \\
\hline Wei et al. [67] & 2013 & $\begin{array}{l}\text { Prevalence of } \\
\text { latent TB } \\
\text { infection (LTBI) }\end{array}$ & China & $\begin{array}{l}210 \text { health care } \\
\text { workers in a chest } \\
\text { hospital in } \\
\text { Harbin }\end{array}$ & Prospective & $\begin{array}{l}\text { Questionnaire on } \\
\text { occupational history; } \\
\text { participants were tested } \\
\text { with two } \\
\text { interferon-gamma release } \\
\text { assays (QuantiFERON-TB } \\
\text { Gold In-Tube assay } \\
\text { (GFT-GIT) and A.TB) and } \\
\text { TST. Participants were } \\
\text { observed for } 2 \text { years to } \\
\text { check for the development } \\
\text { of active tuberculosis. }\end{array}$ & $\begin{array}{l}\text { Prevalence of LTBI was } 76.5 \% \text { by QFT-GIT, } 65.7 \% \\
\text { by A.TB and } 97.6 \% \text { by TST, which was higher than } \\
\text { that reported in the general population. Working } \\
\text { as a nurse and age }>30 \text { years were independently } \\
\text { associated with increased risk of LTBI. }\end{array}$ \\
\hline $\begin{array}{l}\text { Whitaker et al. } \\
\text { [68] }\end{array}$ & 2013 & $\begin{array}{l}\text { Prevalence and } \\
\text { risk of latent TB } \\
\text { infection (LTBI) }\end{array}$ & Georgia & $\begin{array}{l}319 \text { health care } \\
\text { workers in } \\
\text { Georgia }\end{array}$ & $\begin{array}{l}\text { Prospective } \\
\text { longitudinal }\end{array}$ & $\begin{array}{l}\text { Questionnaire, and tests } \\
\text { for LTBI using the TST and } \\
\text { QuantiFERON-TB Gold } \\
\text { In-Tube Assay (QFT-GIT). } \\
\text { The tests were repeated } \\
6-26 \text { months after baseline. }\end{array}$ & $\begin{array}{l}\text { Prevalence at baseline was } 67 \% \text { by TST and } 46 \% \text { by } \\
\text { QFT-GIT. Health care workers (HCWs) working in } \\
\text { TB health care facilities had a higher prevalence of } \\
\text { positive TST and QTF-GIT. Frequent contact with } \\
\text { TB patients was associated with increased risk of } \\
\text { QTF-GIT positivity only and increasing age was } \\
\text { associated with increased risk of positivity of both } \\
\text { tests. The conversions rates were high at } 22.8 / 100 \\
\text { person-years (QTF-GIT) and } 17.1 / 100 \text { person-years } \\
\text { (TST). Female HCWs had a decreased risk of TST } \\
\text { conversion and older HCWs had an increased risk } \\
\text { of QTF-GIT conversion. }\end{array}$ \\
\hline
\end{tabular}


Table 1. Cont

\begin{tabular}{|c|c|c|c|c|c|c|c|}
\hline Authors & Year & Topic & Origin & Participants & Type of Study & Methods & Findings \\
\hline $\begin{array}{l}\text { Tudor et al. } \\
\text { [69] }\end{array}$ & 2014 & $\begin{array}{l}\text { TB incidence and } \\
\text { risk factors }\end{array}$ & $\begin{array}{l}\text { South } \\
\text { Africa }\end{array}$ & $\begin{array}{l}1313 \text { health care } \\
\text { workers from } \\
3 \text { district } \\
\text { hospitals in } \\
\text { KwaZulu-Natal }\end{array}$ & Retrospective & $\begin{array}{l}\text { Occupational health } \\
\text { medical records of } \\
1313 \text { health care workers } \\
\text { were reviewed during the } \\
\text { period of January } 2006 \text { and } \\
\text { December } 2010 .\end{array}$ & $\begin{array}{l}\text { The TB incidence rate was } \\
\text { 1958/100,000 person-years, which was two-fold } \\
\text { greater than in the general population. An } \\
\text { increased incidence of TB was seen in those } \\
\text { working in TB wards, paediatric wards, outpatient } \\
\text { departments and stores/workshops. Health care } \\
\text { workers living with HIV had a greater incidence of } \\
\text { TB. }\end{array}$ \\
\hline $\begin{array}{l}\text { El-Sokkary } \\
\text { et al. [70] }\end{array}$ & 2015 & $\begin{array}{l}\text { Latent TB } \\
\text { infection (LTBI) } \\
\text { prevalence and } \\
\text { risk factors }\end{array}$ & Egypt & $\begin{array}{l}132 \text { health care } \\
\text { workers from a } \\
\text { chest Hospital in } \\
\text { Zagazig city }\end{array}$ & Cross-sectional & $\begin{array}{l}\text { Questionnaire and tests for } \\
\text { LTBI using the TST and } \\
\text { QuantiFERON-TB Gold } \\
\text { In-Tube Assay (QFT-GIT). }\end{array}$ & $\begin{array}{l}\text { Prevalence was } 28.8 \% \text { by QFT-GIT and } 59.1 \% \text { by } \\
\text { TST. Being a nurse, working }>10 \text { years, smoking } \\
\text { and diabetes were significantly associated with risk } \\
\text { of LTBI. }\end{array}$ \\
\hline $\begin{array}{l}\text { Tudor et al. } \\
\text { [71] }\end{array}$ & 2016 & $\begin{array}{l}\text { Occupational risk } \\
\text { factors for TB }\end{array}$ & $\begin{array}{l}\text { South } \\
\text { Africa }\end{array}$ & $\begin{array}{l}145 \text { health care } \\
\text { workers ( } 54 \text { cases, } \\
91 \text { controls) from } \\
3 \text { district } \\
\text { hospitals in } \\
\text { KwaZulu-Natal }\end{array}$ & Case control & $\begin{array}{l}\text { Cases were identified from } \\
\text { the occupational health } \\
\text { medical records between } \\
\text { January } 2006 \text { and } \\
\text { December } 2010 .\end{array}$ & $\begin{array}{l}\text { Health care workers with HIV and those who } \\
\text { spent time working in areas with tuberculosis } \\
\text { patients were at an increased risk of TB. }\end{array}$ \\
\hline He et al. [72] & 2017 & $\begin{array}{l}\text { Pulmonary } \\
\text { tuberculosis } \\
\text { status among } \\
\text { health care } \\
\text { workers as } \\
\text { diagnosed with } \\
\text { low-dose CT }\end{array}$ & China & $\begin{array}{l}1012 \text { health care } \\
\text { workers from the } \\
\text { Beijing Chest } \\
\text { Hospital }\end{array}$ & Retrospective & $\begin{array}{l}\text { Health examination data } \\
\text { of } 1012 \text { health care workers } \\
\text { which included low-dose } \\
\text { lung CT examinations } \\
\text { from January } 2012 \text { to } \\
\text { November } 2015 \text { were } \\
\text { analysed. }\end{array}$ & $\begin{array}{l}\text { The incidence and prevalence rates of active TB } \\
\text { were }>2.8 \text { times and }>4.1 \text { times greater than that of } \\
\text { the general population of China. The majority } \\
\text { ( } 78.9 \% \text { ) of the health care workers with active TB } \\
\text { worked in high-risk areas such as TB wards, } \\
\text { outpatient clinics and radiology departments. }\end{array}$ \\
\hline $\begin{array}{l}\text { Erawati and } \\
\text { Andriany [73] }\end{array}$ & 2020 & $\begin{array}{l}\text { Latent TB } \\
\text { infection (LTBI) } \\
\text { prevalence and } \\
\text { risk factors }\end{array}$ & Indonesia & $\begin{array}{l}195 \text { health care } \\
\text { workers from } \\
34 \text { primary health } \\
\text { centres in } \\
\text { Semarang }\end{array}$ & Cross-sectional & $\begin{array}{l}\text { Questionnaire and tests for } \\
\text { LTBI using } \\
\text { QuantiFERON-TB Gold } \\
\text { In-Tube Assay (QFT-GIT). }\end{array}$ & $\begin{array}{l}\text { Prevalence of LTBI was } 23.6 \% \text {. Health care workers } \\
\text { with comorbidities were at increased risk of LTBI. }\end{array}$ \\
\hline
\end{tabular}

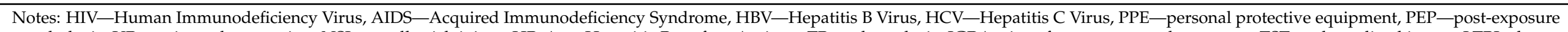

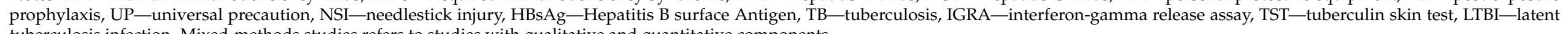
tuberculosis infection. Mixed-methods studies refers to studies with qualitative and quantitative components. 
Table 2. The characteristics of the studies $(\mathrm{n}=22)$ on exposure to psychosocial hazards (arranged in chronological order according to the year of publication).

\begin{tabular}{|c|c|c|c|c|c|c|c|}
\hline Authors & Year & Topic & Origin & Participants & Type of Study & Methods & Findings \\
\hline \multicolumn{8}{|c|}{ I. Workplace Violence } \\
\hline Kisa et al. [74] & 2002 & $\begin{array}{c}\text { Sexual } \\
\text { harassment and } \\
\text { work } \\
\text { productivity }\end{array}$ & Turkey & $\begin{array}{l}215 \text { nurses from } \\
\text { two hospitals in } \\
\text { Turkey }\end{array}$ & Cross-sectional & $\begin{array}{l}\text { Questionnaires on sexual } \\
\text { harassment and work } \\
\text { performance. }\end{array}$ & $\begin{array}{l}73 \% \text { reported being sexually harassed. The main } \\
\text { perpetrators were physicians and patients, and } \\
\text { these incidents occurred more commonly in the } \\
\text { in-patient clinics. } 45 \% \text { reported a decline in work } \\
\text { productivity following the incidents. }\end{array}$ \\
\hline $\begin{array}{l}\text { Kamchuchat } \\
\text { et al. [75] }\end{array}$ & 2008 & $\begin{array}{l}\text { Workplace } \\
\text { violence }\end{array}$ & Thailand & $\begin{array}{l}545 \text { nurses } \\
\text { working in a } \\
\text { general hospital } \\
\text { in southern } \\
\text { Thailand }\end{array}$ & Mixed methods & $\begin{array}{l}\text { Questionnaire modified } \\
\text { from one developed by the } \\
\text { Joint Program on } \\
\text { Workplace Violence in the } \\
\text { Health Sector and key } \\
\text { informant interviews } \\
(\mathrm{n}=17) .\end{array}$ & $\begin{array}{l}\text { The } 12-\text { month prevalence was } 38.9 \% \text { for verbal } \\
\text { abuse, } 3.1 \% \text { for physical abuse and } 0.7 \% \text { for sexual } \\
\text { harassment. The main perpetrators of verbal and } \\
\text { physical abuse were patients and their family, } \\
\text { while co-workers were the main perpetrators for } \\
\text { sexual harassment. Younger age and working in } \\
\text { high-risk areas (out-patient unit, emergency units, } \\
\text { operating theatre, medical and surgical units) were } \\
\text { associated with an increased risk of violence. }\end{array}$ \\
\hline $\begin{array}{l}\text { Aydin et al. } \\
\text { [76] }\end{array}$ & 2009 & $\begin{array}{l}\text { Workplace } \\
\text { violence }\end{array}$ & Turkey & $\begin{array}{l}522 \text { general } \\
\text { practitioners } \\
\text { from } 48 \text { cities }\end{array}$ & Cross-sectional & $\begin{array}{l}\text { Questionnaire on } \\
\text { workplace violence. }\end{array}$ & $\begin{array}{l}82.2 \% \text { reported experiencing violence at work. } \\
\text { Verbal abuse was the most common }(89.3 \%) \text {, } \\
\text { followed by physical violence }(7.9 \%), \text { economic } \\
(1.7 \%) \text { and sexual violence }(1.1 \%) \text {. Verbal and } \\
\text { sexual violence was more common in women and } \\
\text { physical and economic violence more common in } \\
\text { men. Patients and their relatives was the most } \\
\text { common source }(91.1 \%) \text {. }\end{array}$ \\
\hline $\begin{array}{l}\text { Gimeno et al. } \\
\text { [77] }\end{array}$ & 2010 & $\begin{array}{l}\text { Prevalence of } \\
\text { verbal abuse and } \\
\text { its association } \\
\text { with safety } \\
\text { climate at work }\end{array}$ & Costa Rica & $\begin{array}{l}625 \text { health care } \\
\text { workers working } \\
\text { in } 10 \text { public } \\
\text { hospitals in Costa } \\
\text { Rica }\end{array}$ & Cross-sectional & $\begin{array}{l}\text { Questionnaires on safety } \\
\text { climate and verbal abuse. }\end{array}$ & $\begin{array}{l}83.9 \% \text { of the participants reported low safety } \\
\text { climate levels. Prevalence of verbal abuse from all } \\
\text { sources was } 78.2 \% \text {, with the most common being } \\
\text { abuse from co-workers and patients. The odds of } \\
\text { experiencing verbal abused increased with lower } \\
\text { levels of safety climate. }\end{array}$ \\
\hline
\end{tabular}


Table 2. Cont

\begin{tabular}{|c|c|c|c|c|c|c|c|}
\hline Authors & Year & Topic & Origin & Participants & Type of Study & Methods & Findings \\
\hline $\begin{array}{l}\text { Atan et al. } \\
\text { [78] }\end{array}$ & 2012 & $\begin{array}{l}\text { Workplace } \\
\text { violence }\end{array}$ & Turkey & $\begin{array}{l}441 \text { nurses from } \\
6 \text { university } \\
\text { hospitals }\end{array}$ & Cross-sectional & $\begin{array}{l}\text { Questionnaires on } \\
\text { workplace violence in the } \\
\text { past year. }\end{array}$ & $\begin{array}{l}60.8 \% \text { reported some form of workplace violence, } \\
59.4 \% \text { verbal violence and } 16.6 \% \text { physical violence. } \\
\text { The sources for verbal violence were patients } \\
(47.4 \%) \text {, visitors }(39.5 \%) \text {, and health staff }(10.7 \%) \\
\text { and for physical violence were patients }(14.3 \%) \text {, } \\
\text { visitors }(5.0 \%) \text { and health staff }(0.5 \%) \text {. Of those } \\
\text { who experienced violence, } 42.9 \% \text { reported a } \\
\text { negative impact on their physical and/or } \\
\text { psychological health and } 42.9 \% \text { reported a negative } \\
\text { impact on work performance. }\end{array}$ \\
\hline $\begin{array}{l}\text { Khademloo } \\
\text { et al. [79] }\end{array}$ & 2013 & $\begin{array}{l}\text { Prevalence of } \\
\text { physical and } \\
\text { verbal abuse }\end{array}$ & Iran & $\begin{array}{l}271 \text { nurses from } \\
5 \text { hospitals in the } \\
\text { north of Iran }\end{array}$ & Cross-sectional & $\begin{array}{l}\text { Questionnaire on physical } \\
\text { and verbal abuse } \\
\text { experienced in the last year } \\
\text { (Staff Observation Scale } \\
\text { Revised (SOAS-R)). }\end{array}$ & $\begin{array}{l}95.9 \% \text { reported verbal abuse; the sources were } \\
\text { patients }(30.3 \%) \text {, family members }(53.4 \%) \text {, and } \\
\text { co-workers }(16.1 \%) .29 .1 \% \text { reported physical abuse; } \\
\text { the sources were patients ( } 44.3 \%) \text { and family } \\
\text { members }(55.6 \%) \text {. }\end{array}$ \\
\hline $\begin{array}{l}\text { da Silva et al. } \\
\text { [80] }\end{array}$ & 2015 & $\begin{array}{l}\text { Workplace } \\
\text { violence and its } \\
\text { association with } \\
\text { depression }\end{array}$ & Brazil & $\begin{array}{l}2940 \text { primary } \\
\text { health care } \\
\text { workers from } \\
66 \text { health centres } \\
\text { in Sao Paolo }\end{array}$ & Cross-sectional & $\begin{array}{l}\text { Questionnaire on } \\
\text { workplace violence } \\
\text { (adapted from a WHO } \\
\text { questionnaire on domestic } \\
\text { violence), and depression } \\
\text { and depressive symptoms } \\
\text { (Brazilian version of the } \\
\text { nine-item Patient Health } \\
\text { Questionnaire). }\end{array}$ & $\begin{array}{l}\text { The frequencies of violence experienced at work } \\
\text { were: insults }(44.9 \%) \text {, witnessing violence }(29.5 \%) \text {, } \\
\text { threats }(24.8 \%) \text {, and physical aggression }(2.3 \%) \text {. } \\
\text { Exposure to violence was positively associated } \\
\text { with depressive symptoms and probable major } \\
\text { depression. }\end{array}$ \\
\hline Baig et al. [81] & 2018 & $\begin{array}{l}\text { Prevalence of } \\
\text { workplace } \\
\text { violence }\end{array}$ & Pakistan & $\begin{array}{l}822 \text { health care } \\
\text { workers from } \\
\text { hospitals, } \\
\text { non-government } \\
\text { organizations } \\
\text { and ambulance } \\
\text { services in } \\
\text { Karachi }\end{array}$ & Mixed methods & $\begin{array}{l}\text { Questionnaires on } \\
\text { workplace violence; and } \\
42 \text { in-depth interviews and } \\
17 \text { focus group discussions. }\end{array}$ & $\begin{array}{l}33.5 \% \text { had experienced violence in the past year. } \\
\text { Verbal violence was more common }(30.5 \%) \text { than } \\
\text { physical violence }(14.6 \%) \text {. The main source was } \\
\text { from people who accompanied patients ( } 58.1 \%) \text {. } \\
\text { The main perceived causes of violence were failure } \\
\text { to meet the expectations of patients, } \\
\text { communication gaps, poor quality of services, } \\
\text { inadequate security in facilities, heavy workloads, } \\
\text { and lack of training to respond to violence. }\end{array}$ \\
\hline
\end{tabular}


Table 2. Cont

\begin{tabular}{|c|c|c|c|c|c|c|c|}
\hline Authors & Year & Topic & Origin & Participants & Type of Study & Methods & Findings \\
\hline $\begin{array}{c}\text { Zhao et al. } \\
\text { [82] }\end{array}$ & 2018 & $\begin{array}{l}\text { Prevalence of } \\
\text { workplace } \\
\text { violence and } \\
\text { association with } \\
\text { mental health }\end{array}$ & China & $\begin{array}{l}886 \text { nurses from } \\
8 \text { tertiary } \\
\text { hospitals in } \\
\text { Heilongjiang } \\
\text { Province }\end{array}$ & Cross-sectional & $\begin{array}{l}\text { Questionnaires on } \\
\text { workplace violence } \\
\text { (Workplace Violence Scale), } \\
\text { anxiety (Self-rating } \\
\text { Anxiety Scale) and } \\
\text { depression (Self-rating } \\
\text { Depression Scale). }\end{array}$ & $\begin{array}{l}67.2 \% \text { reported workplace violence. Workplace } \\
\text { violence was positively associated with anxiety } \\
\text { and depression. Service years played a moderating } \\
\text { role in the relationship between workplace } \\
\text { violence and anxiety, and gender played a } \\
\text { moderating role in the association between } \\
\text { workplace violence and depression. }\end{array}$ \\
\hline $\begin{array}{c}\text { Abate et al. } \\
\text { [83] }\end{array}$ & 2019 & $\begin{array}{c}\text { Workplace } \\
\text { violence and } \\
\text { associated factors }\end{array}$ & Ethiopia & $\begin{array}{l}435 \text { health care } \\
\text { workers from a } \\
\text { tertiary care } \\
\text { mental hospital } \\
\text { in Addis Ababa }\end{array}$ & Cross-sectional & $\begin{array}{l}\text { ILO/ICN/WHO/PSI } \\
\text { Workplace Violence in the } \\
\text { Health Sector Country } \\
\text { Case Study Questionnaire. }\end{array}$ & $\begin{array}{l}62.1 \% \text { reported verbal violence, } 36.8 \% \text { physical } \\
\text { violence and } 21.8 \% \text { sexual harassment. } \\
\text { Age }>31 \text { years and contact with patients were the } \\
\text { associated factors. }\end{array}$ \\
\hline $\begin{array}{l}\text { Yenealem } \\
\text { et al. [84] }\end{array}$ & 2019 & $\begin{array}{l}\text { Prevalence and } \\
\text { risk factors for } \\
\text { violence at work }\end{array}$ & Ethiopia & $\begin{array}{l}531 \text { health care } \\
\text { workers from } \\
\text { Gondar city }\end{array}$ & Cross-sectional & $\begin{array}{l}\text { Questionnaires adapted } \\
\text { from the } \\
\text { ILO/ICN/WHO/PSI } \\
\text { Workplace Violence in the } \\
\text { Health Sector Country } \\
\text { Case Study Questionnaire. }\end{array}$ & $\begin{array}{l}58.2 \% \text { reported experiencing some form of } \\
\text { violence, of which } 53.1 \% \text { reported verbal abuse, } \\
22 \% \text { physical attacks, and } 7.2 \% \text { sexual harassment. } \\
\text { Working in emergency departments, working in } \\
\text { shifts, having less work experience and being a } \\
\text { nurse was associated with an increased risk of } \\
\text { violence. }\end{array}$ \\
\hline $\begin{array}{c}\text { Hacer and Ali } \\
\text { [85] }\end{array}$ & 2020 & $\begin{array}{c}\text { Workplace } \\
\text { violence and its } \\
\text { association with } \\
\text { burnout }\end{array}$ & Turkey & $\begin{array}{l}310 \text { physicians } \\
\text { from Ordu } \\
\text { province }\end{array}$ & Cross-sectional & $\begin{array}{l}\text { Questionnaires on } \\
\text { workplace violence and } \\
\text { the Maslach Burnout } \\
\text { Inventory. }\end{array}$ & $\begin{array}{l}93.2 \% \text { reported experiencing verbal violence, } 86.1 \% \\
\text { psychological violence and } 22.6 \% \text { physical violence. } \\
\text { The most common source of violence were patients } \\
\text { and their relatives. Emotional exhaustion and } \\
\text { depersonalization scores were significantly higher } \\
\text { in those who had experienced violence. }\end{array}$ \\
\hline \multicolumn{8}{|c|}{ II. Burnout } \\
\hline $\begin{array}{c}\text { Ashkar et al. } \\
{[86]}\end{array}$ & 2009 & $\begin{array}{c}\text { Prevalence of } \\
\text { burnout }\end{array}$ & Lebanon & $\begin{array}{l}155 \text { resident } \\
\text { doctors from } \\
2 \text { tertiary care } \\
\text { hospitals in } \\
\text { Beirut }\end{array}$ & Cross-sectional & $\begin{array}{l}\text { Questionnaires on } \\
\text { occupational history and } \\
\text { the Maslach Burnout } \\
\text { Inventory for Health } \\
\text { Service Workers. }\end{array}$ & $\begin{array}{l}80 \% \text { reported high levels of burnout in at least one } \\
\text { domain. Prevalence according to subscales was: } \\
\text { high levels of emotional exhaustion (EE) - } 67.7 \% \text {, } \\
\text { high depersonalisation (DP) scores-47.1\% and } \\
\text { low levels of personal accomplishment } \\
\text { (PA) - } 23.9 \% \text {. Working }>80 \mathrm{~h} / \text { week, experiencing } \\
\text { a major stress, getting > eight calls per month, and } \\
\text { being female increased the risk of burnout }\end{array}$ \\
\hline
\end{tabular}


Table 2. Cont.

\begin{tabular}{|c|c|c|c|c|c|c|c|}
\hline Authors & Year & Topic & Origin & Participants & Type of Study & Methods & Findings \\
\hline $\begin{array}{c}\text { Ayala and } \\
\text { Carnero [87] }\end{array}$ & 2013 & $\begin{array}{c}\text { Demographic } \\
\text { and occupational } \\
\text { determinants of } \\
\text { burnout }\end{array}$ & Peru & $\begin{array}{l}93 \text { nurses } \\
\text { working in acute } \\
\text { and critical care } \\
\text { departments in a } \\
\text { referral military } \\
\text { hospital in Lima }\end{array}$ & Cross-sectional & $\begin{array}{l}\text { Questionnaires on } \\
\text { occupational history and } \\
\text { the Maslach Burnout } \\
\text { Inventory. }\end{array}$ & $\begin{array}{l}\text { Higher emotional exhaustion scores were } \\
\text { associated with having children and inversely } \\
\text { associated with time working in the current } \\
\text { department. Higher depersonalisation scores were } \\
\text { associated with being single and working in the } \\
\text { emergency room or intensive care unit. Higher } \\
\text { personal achievement scores were associated with } \\
\text { having children. }\end{array}$ \\
\hline $\begin{array}{l}\text { Zubairi and } \\
\text { Noordin [88] }\end{array}$ & 2016 & $\begin{array}{l}\text { Prevalence of } \\
\text { burnout and risk } \\
\text { factors }\end{array}$ & Pakistan & $\begin{array}{l}82 \text { resident } \\
\text { doctors working } \\
\text { in a university } \\
\text { hospital in } \\
\text { Karachi }\end{array}$ & Cross-sectional & $\begin{array}{l}\text { Questionnaires on } \\
\text { occupational history and } \\
\text { the Maslach Burnout } \\
\text { Inventory }\end{array}$ & $\begin{array}{l}74.4 \% \text { reported high levels of burnout on at least } \\
\text { one subscale, and } 12.2 \% \text { reported burnout on all } \\
\text { the three subscales. Prevalence according to } \\
\text { subscales was: high levels of EE-60\%, high DP } \\
\text { scores-38\% and low levels of PA-32\%. Workload } \\
\text { dissatisfaction, length of working hours, } \\
\text { relationship with co-workers and lack of autonomy } \\
\text { were associated with an increased risk of burnout }\end{array}$ \\
\hline $\begin{array}{l}\text { Colindres } \\
\text { et al. [89] }\end{array}$ & 2018 & $\begin{array}{l}\text { Association of } \\
\text { psychosocial } \\
\text { work } \\
\text { environment, } \\
\text { burnout and } \\
\text { compliance with } \\
\text { infection control } \\
\text { measures }\end{array}$ & Ecuador & $\begin{array}{l}333 \text { nurses in four } \\
\text { acute care } \\
\text { facilities in } \\
\text { Ecuador }\end{array}$ & Cross-sectional & $\begin{array}{l}\text { Questionnaires on } \\
\text { effort-reward imbalance, } \\
\text { burnout (Copenhagen } \\
\text { Burnout Inventory scale) } \\
\text { and infection control } \\
\text { compliance (modified } \\
\text { Johns Hopkins University. } \\
\text { School of Hygiene and } \\
\text { Public Health Safety } \\
\text { Climate Questionnaire). }\end{array}$ & $\begin{array}{l}21 \% \text { of nurses experienced effort reward imbalance } \\
\text { and } 35.8 \% \text { had work-related burnout. } 44.2 \% \\
\text { reported adhering to infection control practices. } \\
\text { Increased effort-reward imbalance was associated } \\
\text { with an increased risk of burnout. Burnout was } \\
\text { independently associated with decreased } \\
\text { adherence to infection control practices. }\end{array}$ \\
\hline $\begin{array}{c}\text { Khan et al. } \\
\text { [90] }\end{array}$ & 2019 & $\begin{array}{c}\text { Job stress and } \\
\text { burnout }\end{array}$ & Pakistan & $\begin{array}{l}447 \text { anaesthesiolo- } \\
\text { gists from tertiary } \\
\text { hospitals in } \\
\text { Lahore and } \\
\text { Karachi }\end{array}$ & Cross-sectional & $\begin{array}{l}\text { Questionnaires on } \\
\text { occupational history and } \\
\text { the Maslach Burnout } \\
\text { Inventory. }\end{array}$ & $\begin{array}{l}39.4 \% \text { showed moderate to high levels emotional } \\
\text { exhaustion, } 68.4 \% \text { moderate to high levels of } \\
\text { depersonalization, and } 50.3 \% \text { moderate to high } \\
\text { levels of burnout in personal achievements. } \\
\text { Working in Lahore, }>2 \text { nights on call per week, } \\
\text { and }>40 \text { h/week work inside the operating room } \\
\text { were associated with burnout. }\end{array}$ \\
\hline
\end{tabular}


Table 2. Cont

\begin{tabular}{|c|c|c|c|c|c|c|c|}
\hline Authors & Year & Topic & Origin & Participants & Type of Study & Methods & Findings \\
\hline $\begin{array}{l}\text { Mumbwe } \\
\text { et al. [91] }\end{array}$ & 2020 & $\begin{array}{c}\text { Prevalence of } \\
\text { burnout }\end{array}$ & Zambia & $\begin{array}{l}160 \text { anaesthesia } \\
\text { providers } \\
\text { (physicians and } \\
\text { non-physicians) } \\
\text { in Zambia }\end{array}$ & Cross-sectional & $\begin{array}{l}\text { Questionnaires on } \\
\text { occupational history and } \\
\text { the Maslach Burnout } \\
\text { Inventory. }\end{array}$ & $\begin{array}{l}\text { Burnout was seen in } 51.3 \% \text { of participants. } \\
\text { Prevalence according to subscales was: high levels } \\
\text { of EE-66.3\%, high DP scores-45\% and low levels } \\
\text { of PA-23.8\%. Not being a physician and not } \\
\text { having the right team to work with were } \\
\text { significantly associated with burnout. }\end{array}$ \\
\hline \multicolumn{8}{|c|}{ III. Work Environment and Job Satisfaction } \\
\hline $\begin{array}{l}\text { Ayamolowo } \\
\text { et al. [93] }\end{array}$ & 2013 & $\begin{array}{l}\text { Work } \\
\text { environment and } \\
\text { job satisfaction }\end{array}$ & Nigeria & $\begin{array}{l}161 \text { nurses } \\
\text { working in public } \\
\text { primary health } \\
\text { care facilities in } \\
\text { Ekiti State }\end{array}$ & Cross-sectional & $\begin{array}{l}\text { Questionnaires assessing } \\
\text { work environment } \\
\text { (adapted from the World } \\
\text { Health Professions } \\
\text { Alliance checklist on } \\
\text { environment for health } \\
\text { care professionals) and job } \\
\text { satisfaction (Minnesota } \\
\text { Satisfaction Questionnaire } \\
\text { (MSQ). }\end{array}$ & $\begin{array}{l}44 \% \text { of the nurses perceived their work } \\
\text { environment to be of average quality and } 31 \% \text { as } \\
\text { high quality. A majority }(67.1 \%) \text { of nurses reported } \\
\text { low degrees of job satisfaction. There was a } \\
\text { positive correlation between overall work } \\
\text { environment and job satisfaction. }\end{array}$ \\
\hline $\begin{array}{l}\text { Ogunlade } \\
\text { and Ogun- } \\
\text { fowokan. } \\
\text { [94] }\end{array}$ & 2014 & $\begin{array}{l}\text { Nurses' } \\
\text { experiences and } \\
\text { satisfaction with } \\
\text { night shift work }\end{array}$ & Nigeria & $\begin{array}{l}186 \text { nurses who } \\
\text { did a roster } \\
\text { including night } \\
\text { shift in } 2 \text { tertiary } \\
\text { hospitals in Ile-Ife }\end{array}$ & Cross-sectional & $\begin{array}{l}\text { Questionnaires assessing } \\
\text { experiences and } \\
\text { satisfaction during night } \\
\text { shift work. }\end{array}$ & $\begin{array}{l}\text { Overall, } 55.4 \% \text { were fairly satisfied with their night } \\
\text { shifts as compared to } 1.6 \% \text { who were very satisfied } \\
\text { and } 43.0 \% \text { who were satisfied. Inadequate staffing } \\
\text { and equipment for protection from hazards were } \\
\text { the factors that contributed to the low satisfaction } \\
\text { with night shifts. }\end{array}$ \\
\hline $\begin{array}{c}\text { Ayalew and } \\
\text { Workineh [95] }\end{array}$ & 2019 & $\begin{array}{l}\text { Job satisfaction } \\
\text { and associated } \\
\text { factors }\end{array}$ & Ethiopia & $\begin{array}{l}220 \text { nurses from } \\
\text { public health } \\
\text { facilities in Bahir } \\
\text { Dar city }\end{array}$ & Cross-sectional & $\begin{array}{l}\text { Questionnaire on job } \\
\text { satisfaction using the Job } \\
\text { satisfaction scale and } \\
\text { Minnesota Questionnaire. }\end{array}$ & $\begin{array}{l}43.6 \% \text { were satisfied with their job. Advancement, } \\
\text { recognition and work security were positively } \\
\text { associated with job satisfaction. }\end{array}$ \\
\hline
\end{tabular}

Note: Mixed-methods studies refers to studies with qualitative and quantitative components. 
Table 3. The characteristics of the studies $(n=17)$ on exposure to ergonomic hazards (arranged in chronological order according to the year of publication).

\begin{tabular}{|c|c|c|c|c|c|c|c|}
\hline Authors & Year & Topic & Origin & Participants & Type of Study & Methods & Findings \\
\hline $\begin{array}{l}\text { Smith et al. } \\
\text { [96] }\end{array}$ & 2004 & $\begin{array}{l}\text { Musculoskeletal } \\
\text { complaints } \\
\text { (MSCs) and } \\
\text { psychosocial risk } \\
\text { factors }\end{array}$ & China & $\begin{array}{l}282 \text { nurses from a } \\
\text { tertiary care } \\
\text { hospital in } \\
\text { Shijiazhuang city }\end{array}$ & Cross-sectional & $\begin{array}{c}\text { Standardized Nordic } \\
\text { Questionnaire. }\end{array}$ & $\begin{array}{l}\text { Prevalence of MSCs in the past } 12 \text { months } \\
\text { was } 70 \% \text {. The most common site was the } \\
\text { lower back }(56 \%) \text { followed by the neck }(45 \%) \text {, } \\
\text { shoulder }(40 \%) \text { and upper back ( } 37 \%) \text {. High } \\
\text { mental pressure, limited work support and } \\
\text { performing boring and tedious tasks were } \\
\text { associated with increased risk of MSCs. }\end{array}$ \\
\hline Tezel [97] & 2005 & $\begin{array}{l}\text { Musculoskeletal } \\
\text { complaints } \\
\text { (MSCs) }\end{array}$ & Turkey & $\begin{array}{l}120 \text { nurses from } \\
4 \text { hospitals in } \\
\text { Ezrurum }\end{array}$ & Cross-sectional & $\begin{array}{l}\text { Standardized Nordic } \\
\text { Questionnaire. }\end{array}$ & $\begin{array}{l}90 \% \text { reported at least one MSC in the past } \\
6 \text { months. Low-back pain was the most } \\
\text { common }(69 \%) \text {, followed by neck }(54 \%) \text { and } \\
\text { shoulder }(46 \%) \text { pain. }\end{array}$ \\
\hline $\begin{array}{l}\text { Fabunmi et al. } \\
\text { [98] }\end{array}$ & 2008 & $\begin{array}{l}\text { Prevalence of } \\
\text { musculoskeletal } \\
\text { disorders (MSD) }\end{array}$ & Nigeria & $\begin{array}{l}214 \text { nurses in a } \\
\text { university hospital } \\
\text { in Ibadan }\end{array}$ & Cross-sectional & $\begin{array}{c}\text { Standardized Nordic } \\
\text { Questionnaire. }\end{array}$ & $\begin{array}{l}90.7 \% \text { reported experiencing MSDs in the } \\
\text { past } 12 \text { months. Low-back pain was the most } \\
\text { common }(78 \%) \text {. Job inexperience, volume } \\
\text { and type of work were the predisposing } \\
\text { factors. }\end{array}$ \\
\hline $\begin{array}{l}\text { de Castro } \\
\text { et al. [99] }\end{array}$ & 2009 & $\begin{array}{l}\text { Work-related } \\
\text { injuries and back } \\
\text { pain }\end{array}$ & Philippines & $\begin{array}{l}690 \text { nurses from } \\
13 \text { regions of the } \\
\text { Philippines who } \\
\text { were attending the } \\
\text { Philippines Nurses } \\
\text { Association annual } \\
\text { national } \\
\text { convention }\end{array}$ & Cross-sectional & $\begin{array}{l}\text { Questionnaires on work } \\
\text { related injuries/illness, } \\
\text { reporting behaviour, and } \\
\text { safety concerns. }\end{array}$ & $\begin{array}{l}38.6 \% \text { reported experiencing at least one } \\
\text { occupational injury/illness in the past year } \\
\text { and } 78.2 \% \text { reported experiencing back pain. } \\
\text { Most of the injuries were not reported. The } \\
\text { most frequent safety concerns reported were } \\
\text { stress and overwork. }\end{array}$ \\
\hline $\begin{array}{l}\text { Karahan et al. } \\
\text { [100] }\end{array}$ & 2009 & $\begin{array}{l}\text { Prevalence of } \\
\text { low-back pain } \\
\text { and risk factors }\end{array}$ & Turkey & $\begin{array}{l}1600 \text { health care } \\
\text { workers from } \\
6 \text { hospitals in } \\
4 \text { Turkish cities }\end{array}$ & Cross-sectional & $\begin{array}{l}\text { Questionnaires on back } \\
\text { pain and occupational } \\
\text { history. }\end{array}$ & $\begin{array}{l}61.3 \% \text { reported at least one occurrence of } \\
\text { low-back pain within the last } 12 \text { months. Age, } \\
\text { female gender, smoking, occupation as a } \\
\text { nurse, work stress and heavy lifting were } \\
\text { associated with increased risks. }\end{array}$ \\
\hline
\end{tabular}


Table 3. Cont.

\begin{tabular}{|c|c|c|c|c|c|c|c|}
\hline Authors & Year & Topic & Origin & Participants & Type of Study & Methods & Findings \\
\hline $\begin{array}{l}\text { Mehrdad et al. } \\
\text { [101] }\end{array}$ & 2010 & $\begin{array}{l}\text { Musculoskeletal } \\
\text { symptoms and } \\
\text { association with } \\
\text { psychosocial } \\
\text { factors }\end{array}$ & Iran & $\begin{array}{l}317 \text { nurses from } \\
\text { the Emam } \\
\text { hospital in } \\
\text { Tehran }\end{array}$ & Cross-sectional & $\begin{array}{l}\text { Standardized Nordic } \\
\text { Questionnaire and General } \\
\text { Nordic questionnaire on } \\
\text { psychosocial work } \\
\text { environment. }\end{array}$ & $\begin{array}{l}95 \% \text { reported complaints in at least one body site } \\
\text { in the past } 12 \text { months. Low back was the most } \\
\text { common site }(73.2 \%) \text {. Higher levels of stress was } \\
\text { associated with increased risk of musculoskeletal } \\
\text { complaints. }\end{array}$ \\
\hline $\begin{array}{c}\text { Tinubu et al. } \\
\text { [102] }\end{array}$ & 2010 & $\begin{array}{l}\text { Work-related } \\
\text { musculoskeletal } \\
\text { disorders } \\
\text { (WMSDs) and } \\
\text { risk factors }\end{array}$ & Nigeria & $\begin{array}{l}128 \text { nurses from } \\
3 \text { hospitals in } \\
\text { Ibidan }\end{array}$ & Cross-sectional & $\begin{array}{l}\text { Standardized Nordic } \\
\text { Questionnaire. }\end{array}$ & $\begin{array}{l}78 \% \text { reported WMSDs in at least one body site in } \\
\text { the past } 12 \text { months. WMSDs occurred mostly in } \\
\text { low back }(44.1 \%) \text {, neck }(28.0 \%) \text {, and knees } \\
(22.4 \%) . \text { Working in the same position for long } \\
\text { periods, lifting/transferring patients, bending or } \\
\text { twisting, and handling many patients were the } \\
\text { commonest risk factors. }\end{array}$ \\
\hline $\begin{array}{l}\text { Arsalani et al. } \\
\text { [103] }\end{array}$ & 2014 & $\begin{array}{c}\text { Prevalence of } \\
\text { musculoskeletal } \\
\text { disorders (MSD) } \\
\text { and risk factors }\end{array}$ & Iran & $\begin{array}{l}520 \text { nurses } \\
\text { working in } \\
10 \text { university } \\
\text { hospitals in } \\
\text { Tehran }\end{array}$ & Cross-sectional & $\begin{array}{l}\text { Standardized Nordic } \\
\text { Questionnaire and } \\
\text { psychosocial working } \\
\text { conditions from the } \\
\text { Copenhagen Psychosocial } \\
\text { Questionnaire. }\end{array}$ & $\begin{array}{l}88 \% \text { reported experiencing MSDs in the past } \\
12 \text { months, with the most common body regions } \\
\text { being the lower back }(65.3 \%) \text {, knees ( } 56.2 \%) \text { and } \\
\text { neck }(49.8 \%) \text {. Physical and psychosocial work } \\
\text { demands and low control over their work, which } \\
\text { lead to work-related stress, increased the risk of } \\
\text { MSDs. Participants also reported inflexible work } \\
\text { schedule, poor quality of devices for transferring } \\
\text { patients, overexertion and job dissatisfaction. }\end{array}$ \\
\hline $\begin{array}{l}\text { Barzideh et al. } \\
\text { [104] }\end{array}$ & 2014 & $\begin{array}{c}\text { Prevalence of } \\
\text { musculoskeletal } \\
\text { disorders (MSD) } \\
\text { and risk factors }\end{array}$ & Iran & $\begin{array}{c}385 \text { nurses } \\
\text { working in } \\
14 \text { educational } \\
\text { hospitals }\end{array}$ & Cross-sectional & $\begin{array}{l}\text { Standardized Nordic } \\
\text { questionnaire and Job } \\
\text { Content Questionnaire. }\end{array}$ & $\begin{array}{l}89.9 \% \text { reported experiencing MSDs in the last } \\
12 \text { months. Lower back pain was the most } \\
\text { common }(61.8 \%) \text {. High psychological and } \\
\text { physical job demands and low decision latitude } \\
\text { were associated with increased risks. }\end{array}$ \\
\hline $\begin{array}{l}\text { Munabi et al. } \\
\text { [105] }\end{array}$ & 2014 & $\begin{array}{c}\text { Prevalence of } \\
\text { musculoskeletal } \\
\text { disorders (MSD) } \\
\text { and risk factors }\end{array}$ & Uganda & $\begin{array}{l}741 \text { nurses from } \\
5 \text { hospitals in } \\
\text { Uganda }\end{array}$ & Cross-sectional & $\begin{array}{l}\text { Questionnaire adapted } \\
\text { from the Standardized } \\
\text { Nordic and standardized } \\
\text { Dutch Musculoskeletal } \\
\text { questionnaires. }\end{array}$ & $\begin{array}{l}80.8 \% \text { had experienced MSDs in the last } \\
12 \text { months. Low-back pain was the most common } \\
(61.9 \%) \text {. Working in a bent or twisted position, } \\
\text { mental exhaustion and being absent from work } \\
\text { for more than } 6 \text { months were associated with an } \\
\text { increased risk. }\end{array}$ \\
\hline
\end{tabular}


Table 3. Cont.

\begin{tabular}{|c|c|c|c|c|c|c|c|}
\hline Authors & Year & Topic & Origin & Participants & Type of Study & Methods & Findings \\
\hline $\begin{array}{l}\text { Yasobant and } \\
\text { Rajkumar } \\
\text { [106] }\end{array}$ & 2014 & $\begin{array}{l}\text { Work-related } \\
\text { musculoskeletal } \\
\text { disorders } \\
\text { (WMSDs), and } \\
\text { risk factors }\end{array}$ & India & $\begin{array}{l}140 \text { health care } \\
\text { workers from a } \\
\text { tertiary care } \\
\text { hospital in Chennai }\end{array}$ & Cross-sectional & $\begin{array}{l}\text { Standardized Nordic } \\
\text { Musculoskeletal } \\
\text { Questionnaire. }\end{array}$ & $\begin{array}{l}50.7 \% \text { reported symptoms in at least one } \\
\text { body site in the past } 12 \text { months. Low back } \\
\text { was the most common site ( } 45.7 \%) \text {. Working } \\
\text { in the same position for long periods, } \\
\text { working in awkward and cramped positions, } \\
\text { and performing repetitive tasks were the } \\
\text { commonest risk factors. }\end{array}$ \\
\hline $\begin{array}{l}\text { Abaraogu } \\
\text { et al. [107] }\end{array}$ & 2017 & $\begin{array}{l}\text { Work-related } \\
\text { musculoskeletal } \\
\text { disorders } \\
\text { (WMSDs) and job } \\
\text { stress }\end{array}$ & Nigeria & $\begin{array}{l}126 \\
\text { physiotherapists } \\
\text { from hospitals in } \\
\text { five states }\end{array}$ & Cross-sectional & $\begin{array}{l}\text { Standardized Nordic } \\
\text { Musculoskeletal } \\
\text { Questionnaire and Job } \\
\text { Content Questionnaire. }\end{array}$ & $\begin{array}{l}82.1 \% \text { reported symptoms in at least one body } \\
\text { site in the last } 12 \text { months. Low back was the } \\
\text { most common site }(57.8 \%) \text {. There were high } \\
\text { levels of stress in most of the job dimensions. } \\
\text { However, no specific domains of job stress } \\
\text { dimensions were associated with WMSDs. }\end{array}$ \\
\hline $\begin{array}{l}\text { Amin et al. } \\
{[108]}\end{array}$ & 2018 & $\begin{array}{l}\text { Prevalence of } \\
\text { self-perceived } \\
\text { emotional } \\
\text { distress and } \\
\text { musculoskeletal } \\
\text { disorders (MSD) }\end{array}$ & Malaysia & $\begin{array}{l}376 \text { nurses working } \\
\text { in public hospitals } \\
\text { in the Klang valley }\end{array}$ & Cross-sectional & $\begin{array}{l}\text { Standardized Nordic } \\
\text { Musculoskeletal } \\
\text { Questionnaire and short } \\
\text { version of the Depression, } \\
\text { Anxiety, and Stress Scale. }\end{array}$ & $\begin{array}{l}73.1 \% \text { had experienced MSDs in the last } \\
12 \text { months and neck was the most common } \\
\text { site }(48.9 \%) .75 \% \text { reported emotional distress. } \\
\text { Stress and anxiety were significantly } \\
\text { associated with an increased risk of MSDs. }\end{array}$ \\
\hline $\begin{array}{l}\text { Dlungwane } \\
\text { et al. [109] }\end{array}$ & 2018 & $\begin{array}{l}\text { Low-back pain } \\
\text { and risk factors }\end{array}$ & South Africa & $\begin{array}{l}242 \text { nurses from a } \\
\text { regional hospital in } \\
\text { KwaZulu-Natal }\end{array}$ & Cross-sectional & $\begin{array}{l}\text { Questionnaire on back } \\
\text { pain and risk factors. }\end{array}$ & $\begin{array}{l}\text { The point prevalence of low-back pain was } \\
59 \% \text {. Frequent bending, maintaining } \\
\text { prolonged positions and transferring patients } \\
\text { were the risk factors. }\end{array}$ \\
\hline $\begin{array}{l}\text { Ike and } \\
\text { Olawumi } \\
\text { [110] }\end{array}$ & 2018 & $\begin{array}{l}\text { Back pain and } \\
\text { risk factors }\end{array}$ & Nigeria & $\begin{array}{l}228 \text { nurses working } \\
\text { in a medical centre } \\
\text { in Abeokuta }\end{array}$ & Cross-sectional & $\begin{array}{l}\text { Questionnaire on back } \\
\text { pain and risk factors. }\end{array}$ & $\begin{array}{l}\text { The point prevalence of back pain was } 39 \% \text {. } \\
\text { Maintaining a particular position for long } \\
\text { periods and lifting patients were common } \\
\text { risk factors. }\end{array}$ \\
\hline $\begin{array}{l}\text { Luan et al. } \\
\text { [111] }\end{array}$ & 2018 & $\begin{array}{l}\text { Prevalence of } \\
\text { musculoskeletal } \\
\text { disorders (MSD) } \\
\text { and risk factors }\end{array}$ & Vietnam & $\begin{array}{l}1179 \text { nurses } \\
\text { working in } \\
15 \text { district hospitals } \\
\text { in Haiphong }\end{array}$ & Cross-sectional & $\begin{array}{c}\text { Standardized Nordic } \\
\text { Questionnaire. }\end{array}$ & $\begin{array}{l}74.7 \% \text { reported symptoms of MSDs in the last } \\
12 \text { months. Low back and neck were the most } \\
\text { common sites ( } 44.4 \% \text { and } 44.1 \%) \text {. Age, } \\
\text { history of musculoskeletal disease, anxiety } \\
\text { and absenteeism in the workplace were } \\
\text { risk factors. }\end{array}$ \\
\hline
\end{tabular}


Table 3. Cont.

\begin{tabular}{|c|c|c|c|c|c|c|c|}
\hline Authors & Year & Topic & Origin & Participants & Type of Study & Methods & Findings \\
\hline $\begin{array}{c}\text { Dong et al. } \\
\text { [112] }\end{array}$ & 2019 & $\begin{array}{c}\text { Prevalence of } \\
\text { musculoskeletal } \\
\text { disorders (MSD) } \\
\text { and risk factors }\end{array}$ & China & $\begin{array}{l}14,720 \text { health care } \\
\text { workers from } 8 \\
\text { tertiary hospitals in } \\
\text { Shandong Province }\end{array}$ & Cross-sectional & $\begin{array}{l}\text { Questionnaire } \\
\text { incorporating the } \\
\text { Standardized Nordic } \\
\text { Musculoskeletal and the } \\
\text { Dutch Musculoskeletal } \\
\text { Questionnaires. }\end{array}$ & $\begin{array}{l}91.2 \% \text { reported symptoms in at least one } \\
\text { body site in the last } 12 \text { months. Low back } \\
\text { was the most common site ( } 72.8 \% \text { ). MSDs } \\
\text { were associated with increased work load, } \\
\text { psychological fatigue, mental stress and } \\
\text { certain ergonomic factors (bending, twisting). }\end{array}$ \\
\hline
\end{tabular}

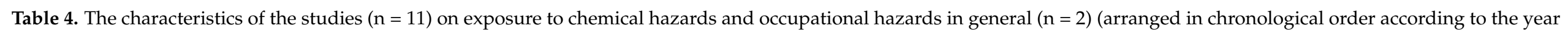
of publication).

\begin{tabular}{|c|c|c|c|c|c|c|c|}
\hline Authors & Year & Topic & Origin & Participants & Type of Study & Methods & Findings \\
\hline \multicolumn{8}{|c|}{ I. Chemical Hazards } \\
\hline $\begin{array}{c}\text { Baykal et al. } \\
\text { [113] }\end{array}$ & 2009 & $\begin{array}{l}\text { Working } \\
\text { conditions and } \\
\text { safe handling } \\
\text { practices of } \\
\text { antineoplastic } \\
\text { drugs }\end{array}$ & Turkey & $\begin{array}{l}171 \text { nurses who } \\
\text { worked in oncology } \\
\text { units and administered } \\
\text { antineoplastic drugs in } \\
\text { nine hospitals in } \\
\text { Istanbul }\end{array}$ & Cross-sectional & $\begin{array}{l}\text { Questionnaires on } \\
\text { working conditions and } \\
\text { safe handling practices of } \\
\text { antineoplastic drugs were } \\
\text { distributed. }\end{array}$ & $\begin{array}{l}94.7 \% \text { of the nurses reported wearing } \\
\text { gloves, } 89.5 \% \text { wore masks, } 52.0 \% \text { wore } \\
\text { gowns and } 18.7 \% \text { wore goggles. } 40.4 \% \\
\text { reported preparing drugs in a biological } \\
\text { safety cabinet, } 37.4 \% \text { said that they } \\
\text { prepared the drugs in the nurses' office } \\
\text { and } 15.8 \% \text { said that they prepared the } \\
\text { drugs in a room that was also used for } \\
\text { other purposes such as meals. }\end{array}$ \\
\hline $\begin{array}{c}\text { Agrawal et al. } \\
\text { [114] }\end{array}$ & 2010 & $\begin{array}{l}\text { Exposure to latex } \\
\text { and latex allergy }\end{array}$ & India & $\begin{array}{c}163 \text { dental } \\
\text { professionals working } \\
\text { in Udaipur city }\end{array}$ & Cross-sectional & $\begin{array}{l}\text { Questionnaires on latex } \\
\text { glove use and symptoms } \\
\text { of latex allergy. }\end{array}$ & $\begin{array}{l}16 \% \text { reported allergy symptoms to latex } \\
\text { gloves. } 81.6 \% \text { wore gloves for }>5 \mathrm{~h} \text { a day. } \\
\text { The number of years of latex gloves use } \\
\text { was significantly associated with allergic } \\
\text { symptoms. }\end{array}$ \\
\hline $\begin{array}{l}\text { Amarasekera } \\
\text { et al. [115] }\end{array}$ & 2010 & $\begin{array}{l}\text { Exposure to latex } \\
\text { and latex allergy }\end{array}$ & Sri-Lanka & $\begin{array}{l}325 \text { health care } \\
\text { workers in a tertiary } \\
\text { care hospital }\end{array}$ & Cross-sectional & $\begin{array}{l}\text { Questionnaires latex } \\
\text { gloves use and symptoms } \\
\text { of latex allergy. }\end{array}$ & $\begin{array}{l}16.3 \% \text { reported latex allergy symptoms. } \\
49.2 \% \text { wore gloves for }>1 \mathrm{~h} \text { a day and } \\
44.2 \% \text { handled other rubber products at } \\
\text { work. Longer duration of working as a } \\
\text { health care worker and using gloves for } \\
>1 \mathrm{~h} / \text { day were the risk factors associated } \\
\text { with allergic symptoms. }\end{array}$ \\
\hline
\end{tabular}


Table 4. Cont.

\begin{tabular}{|c|c|c|c|c|c|c|c|}
\hline Authors & Year & Topic & Origin & Participants & Type of Study & Methods & Findings \\
\hline $\begin{array}{c}\text { Phaswana } \\
\text { and Naidoo } \\
\text { [116] }\end{array}$ & 2013 & $\begin{array}{l}\text { Prevalence of } \\
\text { latex sensitization } \\
\text { and allergy with } \\
\text { the use of } \\
\text { hypoallergenic } \\
\text { powder and } \\
\text { lightly powdered } \\
\text { latex gloves }\end{array}$ & South Africa & $\begin{array}{l}501 \text { health care } \\
\text { workers ( } 337 \text { who used } \\
\text { latex gloves and } 164 \\
\text { administration staff } \\
\text { who did not use latex } \\
\text { gloves) in a tertiary } \\
\text { care hospital in } \\
\text { KwaZulu-Natal }\end{array}$ & Cross-sectional & $\begin{array}{l}\text { Questionnaires on latex } \\
\text { glove use and symptoms } \\
\text { of latex allergy. Skin prick } \\
\text { tests were conducted for } \\
\text { latex sensitization. }\end{array}$ & $\begin{array}{l}\text { Prevalence of latex sensitisation and } \\
\text { allergy in exposed workers was } 7.1 \% \text { and } \\
5.9 \% \text {, respectively; and in unexposed } \\
\text { workers it was } 3.1 \% \text { and } 1.8 \% \text {. } \\
\text { Work-related allergy symptoms were } \\
\text { significantly higher in exposed workers. } \\
\text { A dose-response relationship was } \\
\text { observed for powdered latex gloves. }\end{array}$ \\
\hline $\begin{array}{l}\text { Supapvanich } \\
\text { et al. [117] }\end{array}$ & 2013 & $\begin{array}{l}\text { Exposure to latex } \\
\text { and latex allergy }\end{array}$ & Thailand & $\begin{array}{l}899 \text { nurses from three } \\
\text { hospitals in Thailand }\end{array}$ & Cross-sectional & $\begin{array}{l}\text { Questionnaires on } \\
\text { respiratory and dermal } \\
\text { symptoms that were } \\
\text { attributed to latex gloves } \\
\text { use. }\end{array}$ & $\begin{array}{l}18 \% \text { reported symptoms attributable to } \\
\text { latex gloves use. Dermal symptoms were } \\
\text { more frequently reported, particularly } \\
\text { itchy skin and rash. Using }>15 \text { pairs of } \\
\text { powdered latex gloves/day, using } \\
\text { chlorhexidine and being an operating } \\
\text { theatre nurse were the risk factors } \\
\text { associated dermal symptoms. }\end{array}$ \\
\hline $\begin{array}{l}\text { Köse et al. } \\
\text { [118] }\end{array}$ & 2014 & $\begin{array}{l}\text { Exposure to latex } \\
\text { and latex } \\
\text { sensitization }\end{array}$ & Turkey & $\begin{array}{l}1115 \text { health care } \\
\text { workers from an } \\
\text { education and research } \\
\text { hospital in Izmir }\end{array}$ & Cross-sectional & $\begin{array}{l}\text { Questionnaires on latex } \\
\text { gloves use and symptoms } \\
\text { of latex allergy. Blood was } \\
\text { tested for latex-specific IgE } \\
\text { levels. }\end{array}$ & $\begin{array}{l}\text { Prevalence of latex sensitization was } 4.2 \% \text {. } \\
\text { Latex allergy was more common in } \\
\text { nurses. }\end{array}$ \\
\hline $\begin{array}{l}\text { Supapvanich } \\
\text { et al. [119] }\end{array}$ & 2014 & $\begin{array}{l}\text { Exposure to latex } \\
\text { and latex } \\
\text { sensitization }\end{array}$ & Thailand & $\begin{array}{l}363 \text { nurses from two } \\
\text { tertiary hospitals in } \\
\text { Southern Thailand }\end{array}$ & Cross-sectional & $\begin{array}{l}\text { Questionnaires on use of } \\
\text { latex gloves and symptoms } \\
\text { related to latex use. Latex } \\
\text { sensitization was } \\
\text { confirmed by detecting } \\
\text { anti-latex IgE antibodies } \\
\text { using a solid phase } \\
\text { immunoassay. }\end{array}$ & $\begin{array}{l}\text { The prevalence of latex sensitization was } \\
4.4 \% \text {. The prevalence of latex } \\
\text { sensitization was higher in hospitals } \\
\text { where gloves with higher protein levels } \\
\text { were used. }\end{array}$ \\
\hline
\end{tabular}


Table 4. Cont

\begin{tabular}{|c|c|c|c|c|c|c|c|}
\hline Authors & Year & Topic & Origin & Participants & Type of Study & Methods & Findings \\
\hline $\begin{array}{c}\text { Abbasi et al. } \\
\text { [120] }\end{array}$ & 2016 & $\begin{array}{l}\text { Safe handling } \\
\text { practices of anti- } \\
\text { neoplastic drugs }\end{array}$ & Iran & $\begin{array}{l}86 \text { nurses who worked } \\
\text { in oncology units and } \\
\text { administered } \\
\text { antineoplastic drugs } \\
\text { from six centres of } \\
\text { chemotherapy in } \\
\text { Shiraz }\end{array}$ & Cross-sectional & $\begin{array}{l}\text { Questionnaires on the safe } \\
\text { handling practices were } \\
\text { distributed. Observation of } \\
\text { work practices was } \\
\text { performed using a } \\
\text { check list. }\end{array}$ & $\begin{array}{l}\text { Only about half of the nurses used } \\
\text { personal protective equipment (PPE) } \\
\text { during the administration of the drugs, } \\
\text { and only about } 5 \% \text { used PPE during the } \\
\text { administration and disposal of the drugs. } \\
\text { Biological safety cabinets were used in all } \\
\text { the hospitals and clinics included in } \\
\text { the study. }\end{array}$ \\
\hline Elshaer [121] & 2017 & $\begin{array}{l}\text { Adherence to } \\
\text { control measures } \\
\text { used for handling } \\
\text { of antineoplas- } \\
\text { tic drugs }\end{array}$ & Egypt & $\begin{array}{l}54 \text { nurses and clinical } \\
\text { pharmacists who were } \\
\text { exposed to ADs and } 54 \\
\text { who were not exposed, } \\
\text { working in oncology } \\
\text { centres in } \\
\text { Alexandria city. }\end{array}$ & Cross-sectional & $\begin{array}{l}\text { Questionnaires on adverse } \\
\text { health effects and control } \\
\text { measures were distributed. } \\
\text { Nurses and clinical } \\
\text { pharmacists who were } \\
\text { exposed to ADs were } \\
\text { compared to those who } \\
\text { were not exposed. }\end{array}$ & $\begin{array}{l}\text { Biological safety cabinets and ventilation } \\
\text { devices were used by pharmacists but not } \\
\text { by nurses. Significantly higher } \\
\text { percentages of pharmacists reported safe } \\
\text { handling practices and the use of PPE as } \\
\text { compared to nurses. There was no } \\
\text { medical surveillance program in the } \\
\text { workplace. }\end{array}$ \\
\hline $\begin{array}{c}\text { Alehashem } \\
\text { and Baniasadi } \\
\text { [122] }\end{array}$ & 2018 & $\begin{array}{l}\text { Safe-handling } \\
\text { practices of } \\
\text { antineoplastic } \\
\text { drugs and control } \\
\text { measures }\end{array}$ & Iran & $\begin{array}{l}14 \text { oncology health care } \\
\text { workers filled } 224 \\
\text { questionnaires in a } \\
\text { tertiary care centre }\end{array}$ & Cross-sectional & $\begin{array}{l}7-8 \text { health care workers } \\
\text { worked in the Oncology } \\
\text { ward every day. They } \\
\text { filled the questionnaire on } \\
\text { safe handling practices for } \\
\text { six weeks or } 30 \\
\text { working days. }\end{array}$ & $\begin{array}{l}20.56 \% \text { reported carrying out drug } \\
\text { preparations without any personal } \\
\text { protective equipment. All preparations of } \\
\text { antineoplastic drugs were reported to be } \\
\text { performed in a biological safety cabinet. }\end{array}$ \\
\hline $\begin{array}{l}\text { Bayraktar- } \\
\text { Ekincioglu } \\
\text { et al. [123] }\end{array}$ & 2018 & $\begin{array}{l}\text { Practices and } \\
\text { safety measures } \\
\text { when handling } \\
\text { antineoplas- } \\
\text { tic drugs }\end{array}$ & Turkey & $\begin{array}{c}40 \text { hospital } \\
\text { pharmacists who } \\
\text { handled chemotherapy } \\
\text { from Turkey }\end{array}$ & Cross-sectional & $\begin{array}{l}\text { Questionnaires on } \\
\text { chemotherapy drug } \\
\text { preparation processes and } \\
\text { knowledge on the safety } \\
\text { measures. }\end{array}$ & $\begin{array}{l}\text { The majority }(42.5 \%) \text { reported using } \\
\text { automated chemotherapy units and } 30 \% \\
\text { prepared the drugs manually. The } \\
\text { reported practices were not always } \\
\text { consistent with published } \\
\text { recommendations: use of double glove } \\
(63.6 \%) \text {, glasses }(62.2 \%) \text {, hair cap }(66.7 \%) \text {, } \\
\text { foot covers }(32.3 \%) \text {, masks }(89.1 \%) \text {, coat } \\
(92.1 \%) \text {, closed-system drug transfer set } \\
(70.6 \%) \text {, and biological safety cabinet } \\
(91.7 \%) \text {. }\end{array}$ \\
\hline
\end{tabular}


Table 4. Cont.

\begin{tabular}{|c|c|c|c|c|c|c|c|}
\hline Authors & Year & Topic & Origin & Participants & Type of Study & Methods & Findings \\
\hline \multicolumn{8}{|c|}{ II. Occupational Hazards (General) } \\
\hline $\begin{array}{l}\text { Aluko et al. } \\
\text { [124] }\end{array}$ & 2016 & $\begin{array}{l}\text { Compliance with } \\
\text { control measures }\end{array}$ & Nigeria & $\begin{array}{l}290 \text { health care } \\
\text { workers in Osun } \\
\text { state }\end{array}$ & Cross-sectional & $\begin{array}{l}\text { Questionnaires on } \\
\text { knowledge on } \\
\text { occupational hazards and } \\
\text { their control practices. }\end{array}$ & $\begin{array}{l}\text { Participants were knowledgeable about the } \\
\text { various types of occupational hazards } \\
\text { (biological, chemical, physical, and } \\
\text { ergonomic). Regarding control practices, } \\
96.2 \% \text { wore gloves and } 77.2 \text { practiced correct } \\
\text { body posturing during clinical procedures, } \\
\text { 93.8\% reported safe disposals, and } 62.4 \% \\
\text { were immunized against Hepatitis B. Only } \\
52.1 \% \text { always complied with standard } \\
\text { procedures and the main reasons for } \\
\text { non-compliance were lack of safety } \\
\text { equipment and time constrains. }\end{array}$ \\
\hline $\begin{array}{l}\text { Tait et al. } \\
\text { [125] }\end{array}$ & 2018 & $\begin{array}{c}\text { Biological, } \\
\text { chemical, and } \\
\text { physical hazards } \\
\text { in medical } \\
\text { laboratories }\end{array}$ & Kenya & $\begin{array}{c}204 \text { laboratory } \\
\text { workers in } 108 \\
\text { medical } \\
\text { laboratories in } \\
\text { Kajiado county }\end{array}$ & Cross-sectional & $\begin{array}{l}\text { Questionnaires on } \\
\text { biological, chemical and } \\
\text { physical hazards. }\end{array}$ & $\begin{array}{l}65.6 \% \text { were exposed to } 1+\text { biological hazard, } \\
38.2 \% \text { handled un-labelled and un-marked } \\
\text { chemicals; and } 49.5 \% \text { reported laboratory } \\
\text { equipment dangerously placed. There were a } \\
\text { large number of other risks. Strong } \\
\text { correlations between protective measures } \\
\text { within individuals. Control measures } \\
\text { reported were occupational health and safety } \\
\text { training and supervising staff }(98 \%) \text {, proper } \\
\text { medical waste containers ( } 92.6 \%) \text {, first aid } \\
\text { safety equipment }(36.8 \%) \text {, chemical hygiene } \\
\text { plans }(25 \%) \text { and chemical hoods }(19.1 \%) \text {. }\end{array}$ \\
\hline
\end{tabular}




\section{Discussion}

This study aimed to map and synthesize the available research on occupational hazards among health care workers in LMICs. The research conducted on this topic is quite substantial as evidenced by the 99 articles included in this review. However, half of these studies were on biological hazards, and research on the other types of hazards was minimal in comparison. The findings of this review also show that research on occupational hazards in LMICs has increased considerably in the last decade, perhaps indicating an increasing recognition of occupational health and safety of health care workers in these countries.

\subsection{Biological Hazards}

\subsubsection{Bloodborne Pathogens}

The majority of the literature on biological hazards was on the occupational transmission of bloodborne pathogens, such as Hepatitis B, HIV, and Hepatitis C, through needlestick/sharps injuries and splash accidents. Health care workers from LMICs are at increased risk of transmission of bloodborne pathogens because of the high population prevalence of these diseases and the fact that safety measures to reduce these risks are inadequate [126].

The prevalence of needlestick injuries was variably reported in the studies included in this review, with some studies reporting prevalence in the past year, some over the entire career and a few reporting it in the past 3 months, 6 months and 5 years. The prevalence of needlestick injuries in the past year was reported in 12 studies and showed a wide variation, ranging from $27 \%$ in a study conducted in Nigeria to $82 \%$ in a study conducted in China $[28,33,35,37,40,43,46-48,58,63,64]$. The prevalence of needlestick injuries over the entire career was reported in nine studies and ranged from $32.4 \%$ in a study conducted in Ethiopia to $86.2 \%$ in a study from China $[35,37,43,44,54,61-64]$. The incidence of needlestick injuries was reported in two studies. A study conducted in Kenya reported an incidence rate of 0.97 needlestick injuries per health care worker per year [42] and a study from Turkey reported an incidence of 2.18 exposures/person-years [59].

Needlestick injuries were more common than accidental splashes $[38,45,55,57,58]$, and syringes caused most of the needlestick injuries $[43,45,48,51]$. The highest frequencies of injuries were reported by nurses, doctors (mainly surgeons and interns), dental personnel, and cleaners $[27,28,31,32,43,45,46,48,51,55,57,59,61,63]$. The risk factors for injuries were lack of training, heavy workloads, long working hours, not using gloves, recapping of needles, and using syringes frequently $[37,43,48,51,59]$.

Various risk reduction strategies have been recommended to decrease occupational exposures to bloodborne pathogens, such as the use of standard precautions, vaccination against Hepatitis B, and post-exposure prophylaxis (PEP) for Hepatitis B and HIV [127]. Compliance with standard precautions for infection control was suboptimal as reported in a number of studies from various countries $[29,30,32,33,36,38,47-50,52,54,58,60,64,124,125]$. Barriers to compliance reported were shortage of equipment, inadequate staffing, and lack of training [39]. Unsafe injection practices such as recapping of needles and reusing syringes were also prevalent $[28,34,49,50,53,54]$. Most of the needlestick injuries were not reported and treated $[33,44,56,58]$. There were seven studies that reported on Hepatitis B vaccination status. The vaccination status (completed 3 doses of vaccine) was low in most of the studies ranging from $8 \%$ to $56.1 \%[34,41,46,51,54,60]$, except for a study conducted in China (71\%) [33]. Among all health care workers, vaccination rates were lowest in housekeeping personnel $[34,46]$. There were only three studies that examined post-exposure prophylaxis for HIV and these studies reported a low uptake of PEP by health care workers and that almost half of those who started PEP discontinued the treatment due to side effects of the drugs $[27,32,42]$. There were no studies reporting the use of HBV immunoglobulin for post-exposure prophylaxis for HBV infection, which could be due to its unavailability in LMICs [34]. 
Taken together, the findings of this review show that needlestick and splash injuries are prevalent in LMICs and risk reduction strategies to protect health care workers from these infections are suboptimal.

\subsubsection{Tuberculosis}

A systematic review on tuberculosis among health care workers in LMICs published in 2006 reported a high occupational risk of tuberculosis, with a latent tuberculosis infection (LTBI) prevalence of $54 \%$ (range $33 \%$ to $79 \%$ ), an incidence of $0.5 \%$ to $14.3 \%$ per year, and an attributable risk due to nosocomial exposure from 25 to 5361 per 100,000 per year [25]. As with transmission of bloodborne infections, health care workers in LMIC are at an increased risk of exposure to tuberculosis due to high population tuberculosis rates and limited resources to institute control practices [128]. As compared to high-income countries where there are strict infection control practices to protect health care workers, even basic infection control strategies to reduce transmission in health care facilities in LMICs are lacking and tuberculosis control is mainly focused on case detection and treatment $[128,129]$.

This present review included studies conducted after 2006, and found that occupational tuberculosis transmission is still a significant problem in LMICs. The prevalence of LTBI as reported by five studies in this review ranged from $23.6 \%$ to $76.5 \%$ when assessed using interferon-gamma release assays (IGRAs), and from $59.1 \%$ to $97.6 \%$ when assessed with tuberculin skin tests (TSTs) $[65,67,68,70,73]$. IGRAs are newer tests that use antigens that are more specific and hence are less likely to be affected by previous BCG vaccination status and non-tuberculosis mycobacterial infection, which are the drawbacks of TSTs [129]. In the systematic review, only one study had used IGRAs to detect LTBI prevalence. There was one study in this present review that reported the incidence rates of LTBI test conversion, a prospective study conducted in Georgia from 2009 to 2011, which reported conversion rates of 17.1 per 100 person-years for TST and 22.8 per 100 person years for IGRAs [68].

There were four studies examining active tuberculosis among health care workers in this review $[66,69,71,72]$. A study conducted in India reported a pulmonary tuberculosis incidence rate of 314 per 100,000 person-years among health care workers and that this was 1.86 times higher than that of the general population [66]. Another study conducted in South Africa reported a tuberculosis incidence rate of 1985 per 100,000 person-years among health care workers, which was double the incidence of tuberculosis in the general population [69]. A study conducted in China used low-dose lung CT examinations to detect active tuberculosis, and reported that the incidence and prevalence rates of active tuberculosis in health care workers were $>2.8$ times and $>4.1$ times greater than that of the general population, respectively [72].

The risk factors for acquiring tuberculosis identified in this review were working in high-risk areas (tuberculosis facilities/wards, medical wards, outpatient departments, microbiology laboratories, radiology departments), belonging to certain occupation groups (nurses, microbiology laboratory technicians, and radiology technicians), working for $>10$ years, increasing age, and having co-morbidities such as diabetes and HIV [65-73].

In summary, the prevalence and incidence of LTBI in health care workers in LMICs is very high and active tuberculosis among health care workers is approximately two times higher than that of the general population.

\subsection{Psychosocial Hazards}

\subsubsection{Workplace Violence}

The majority of studies on psychosocial hazards in this review were on workplace violence. Workplace violence has been reported as a significant problem in the health care sector throughout the world [10]. In this review, the prevalence of experiencing some form of violence in the workplace was high and ranged from $60.8 \%$ to $82.2 \%$ [76,78,82]. The prevalence varied depending on the specific type of violence measured (e.g., physical, verbal, sexual). Verbal abuse was the most common type of violence experienced by health 
care workers, with a prevalence ranging from 30.5\% to 95.9\% [75-81,83-85]. The prevalence of physical abuse ranged from $2.3 \%$ to $36.8 \%$ [75,76,78-81,83-85] and that of sexual harassment ranged from $0.7 \%$ to $21.8 \%[75,76,83,84]$. Patients and their families were the most commonly reported perpetrators of verbal and physical abuse, while co-workers and patients were the most commonly reported perpetrators of sexual harassment $[74-79,81,85]$. The risk factors for workplace violence identified in this review were working in certain high-risk areas (out-patient departments, emergency departments, operation theatres and in-patient clinics), lower safety climate levels at work, working in shifts, having heavy workloads and younger age $[74,75,77,81,84]$.

Being a victim of workplace violence can result in a range of negative consequences (psychological, physical, emotional, social, work functioning, quality of care, and financial) [130]. Five studies included in this review reported on the consequences and associations of workplace violence $[74,78,80,82,85]$. Three studies reported on psychological consequences, where exposure to workplace violence was associated with anxiety, depressive symptoms and major depression, and burnout $[80,82,85]$. Two studies reported on work functioning consequences and found that almost half ( $42.9 \%$ and $45 \%$ ) of the participants who experienced workplace violence reported a decline in work productivity [74,78].

\subsubsection{Burnout}

Burnout, as described by Maslach et al. [131], comprises of three dimensions: emotional exhaustion, depersonalization, and low personal accomplishment. Health care workers are known to be at an increased risk of burnout due to the inherent nature of their job which exposes them to high levels of emotional and psychological stress [11]. Burnout has been found to be associated with absenteeism, high turnover rates, low morale, and decrease in the quality of care.

Four of the six studies included in this review examined burnout among doctors (residents and anaesthesiologists) $[86,88,90,91]$ and two studies examined it in acute and critical care nurses $[87,89]$. These studies reported a high prevalence of burnout. The prevalence of high levels of burnout in at least one dimension ranged from $51.3 \%$ to $80 \%$ [86,88,91]. Emotional exhaustion, depersonalization, and low personal accomplishment prevalence ranged from $39.4 \%$ to $67.7 \%, 38 \%$ to $68.4 \%$, and $23.8 \%$ to $50.3 \%$, respectively $[86,88,90,91]$. The work-related risk factors for burnout identified in this review were long working hours, experiencing a major stress at work, not having the right team to work with, lack of autonomy at work, and negative psychosocial work environments (as measured by perceived effort-reward imbalance). Personal risk factors were reported by only two studies and these included female gender, being single and having children [86,87]. Only one study reported on the consequences of burnout and this study found that burnout was independently associated with decreased adherence to infection control practices [89].

\subsubsection{Work Environment and Job Satisfaction}

Two studies included in this review examined job satisfaction and work environment among nurses and reported that more than fifty percent of the nurses (56.4\% to $67.1 \%)$ were not satisfied with their jobs and only $31 \%$ perceived their work environment to be of high quality $[93,95]$. Advancement in the job, recognition, work security and a good work environment were the factors that were reported to be positively associated with job satisfaction. One study examining nurses' satisfaction with night shift work reported that only $43 \%$ of these nurses were satisfied with their night shifts, and the factors associated with the low levels of satisfaction were inadequate staffing and inadequate equipment for protection from hazards [94]. A longitudinal study conducted in China examined psychosocial work environment and intention to leave among nurses and reported a 16.3\% prevalence of intention to leave and an incidence rate of $14.5 \%$ [92]. Increased emotional demands, decreased workplace commitment, decreased meaning of work and decreased job satisfaction were the factors reported to be associated with intention to leave. 
The delivery of quality health care depends largely on the quality of staff delivering these services [132]. Satisfied workers are known to be more efficient and productive, thus contributing to the provision of better quality services. Job dissatisfaction, on the other hand, is associated with absenteeism and higher employee turnover rates. Providing a good work environment is a key factor in improving employee job satisfaction, organizational commitment and intention to remain [14].

In summary, the prevalence of verbal and physical abuse, and burnout were reported as being extremely high in these studies. In addition, satisfaction with work was low. These factors impact on retention of health care workers which is particularly important in the context of LMICs since these countries already face a shortage of health care workers [133].

\subsection{Ergonomic Hazards}

Musculoskeletal disorders are a common cause for work-related disability and absenteeism, resulting in substantial financial consequences in the form of workers' compensation and medical expenditure [134]. Health care worker are at an increased risk of musculoskeletal disorders and there is an extensive body of literature from high-income countries examining these disorders among different occupation groups within the health care sector (nurses, surgeons, physical therapists, dentists) [9,135-137].

The studies on ergonomic hazards included in this review examined prevalence and risk factors of musculoskeletal disorders among health care workers. Thirteen studies examined musculoskeletal disorders using the Nordic Musculoskeletal Questionnaire, mainly among nurses (10/13 studies) [96-98,101-104,106-108,111,112], and four studies examined only low-back pain $[99,100,109,110]$. The prevalence of musculoskeletal complaints in at least one body site in the past twelve months was reported in 12 studies and ranged from $50.7 \%$ to $95 \%$. The most commonly reported body site for these complaints was the lower back (35.3\% to $78.2 \%)$. The prevalence reported for the other regions of the body ranged from $28 \%$ to $49.8 \%$ for the neck, $23.5 \%$ to $52.1 \%$ for the shoulders, $20.7 \%$ to $54 \%$ for the upper back and $11 \%$ to $68.7 \%$ for the knees. There was only one study that examined work-related injuries, in which $38.6 \%$ of the nurses in the study reported experiencing at least one work-related injury in the past twelve months [99].

The occupational physical risk factors for musculoskeletal complaints identified in this review were working in the same position for prolonged periods, working in a bent or twisted position, lifting and transferring patients, handling many patients, and performing repetitive tasks $[102,106,112]$. The occupational psychosocial risk factors for musculoskeletal complaints identified were high levels of stress, anxiety, mental exhaustion, limited support in the workplace, low decision latitude, increased workload, monotonous work, job inexperience, and absenteeism [96,98,101,104,108,111,112].

In summary, there were few studies of musculoskeletal disorders among LMIC health care workers, and they found a very high prevalence of musculoskeletal complaints in at least one body site. There was a lack of studies on work-related injuries.

\subsection{Chemical Hazards}

The studies on chemical hazards in this review mainly examined exposure to latex and latex allergy. Three studies examined the prevalence of latex allergy symptoms among health care workers and reported a prevalence ranging from $16 \%$ to $18 \%[114,115,117]$. The occupational risk factors for latex allergy reported in these studies were the number of years using latex gloves, using latex gloves for $>1 \mathrm{~h}$ per day, using $>15$ pairs of powdered gloves per day, longer duration of working as a health care worker, using chlorhexidine and working as an operation theatre nurse. Two studies conducted in Turkey and Thailand examining the prevalence of latex sensitization by measuring latex-specific $\operatorname{IgE}$ antibody levels reported a prevalence of $4.2 \%$ and $4.4 \%$, respectively, and that the prevalence was higher in hospitals where gloves with higher protein levels were used [118,119].

The use of less allergenic alternatives such as powder-free latex gloves and nitrile gloves has been recommended to control latex exposures among health care workers [12]. 
A study conducted in South Africa examined the prevalence of latex allergy and sensitization after the introduction of hypoallergenic powder-free and lightly powdered latex gloves [116]. The prevalence of latex allergy and sensitization reported in this study was $5.9 \%$ and $7.1 \%$, respectively. The authors concluded that health care workers using hypoallergenic powder-free latex gloves were at risk of developing latex sensitization and recommended that a cost-effective alternative that eliminated latex from the health care environment was required in resource poor countries.

Five studies included in this review examined exposure to antineoplastic drugs, mainly safe handling practices, and reported that adherence to control measures was suboptimal. A study conducted in Egypt reported a lack of medical surveillance programs and training, inadequate handling practices, and low usage of personal protective equipment [121]. Two studies conducted in Turkey found that only about $40 \%$ of participants used biological safety cabinets and that personal protective equipment was not used consistently $[113,123]$. Two studies conducted in Iran reported that antineoplastic drug handling practices were not always consistent with published recommendations [120,122].

Few studies have been conducted on the many chemical hazards in health care work. The only studies which could be found examined exposure to latex and antineoplastic drugs and there were no studies on other chemicals such as cleaning products, disinfectants and diathermy smoke.

Health care workers can also be exposed to physical hazards such as radiation, noise, and slips and falls [12]. However, this review did not identify any studies on exposure to these types of hazards from LMICs.

\subsection{Implications}

This scoping review has revealed that health care workers in LMICs are exposed to a wide range of occupational hazards and that risk reduction strategies and safety measures are inadequately implemented, mainly due to equipment and human resource limitations. To protect health care workers in these countries, first and foremost, occupational health and safety needs to be prioritised. This requires political commitment from governments to increase investments in occupational health and safety programs. Additionally, although development and public health agencies have promoted the importance of health care workers by including the health care workforce as an essential component of sustainable development, these agencies have focused mainly on increasing the numbers and competency of health care workers [138]. There is a need for these agencies to equally address the underlying reasons for health care workers' migration, death and illness in LMICs and to advocate for the provision of safer workplaces for health care workers in these countries.

It is encouraging that research on occupational hazards among health care workers in LMICs has increased considerably in the past decade. However, the majority of the studies in this review were cross-sectional and some of them were of low quality (quality was not an exclusion criteria). In future, larger, more well-designed and prospective studies need to be conducted to make a convincing case for prioritising occupational health and safety of health care workers in these countries. In addition, the majority of the studies were on biological hazards and there were very few studies assessing exposure to chemical hazards. This is as expected since the risks from biological hazards are more apparent in LMICs where the population rates of infectious diseases are high. However, health care workers are also routinely exposed to chemicals that have been linked to chronic diseases such as cancer and asthma. More research is required in this area from LMICs.

\subsection{Strengths and Limitations of the Review}

To our knowledge, this review on exposure to occupational hazards among health care workers is the most comprehensive to date. It was based on a rigorous, systematic search strategy across five large databases with no date restrictions using strict methodological inclusion criteria. 
Although this review has provided an overall synopsis of occupational hazards in health care workers in LMICs, there are some limitations to this study. First, the quality of the included studies was not assessed, so the review is inclusive of all articles irrespective of their quality. Second, only articles published in English were included, which might have resulted in the omission of data published in other languages. Thirdly, there is a possibility that all data may not have been captured by the search strategy, particularly if the articles were published in journals not indexed in Medline. Lastly, this review also excluded night shift work, which is an important occupational risk for health care workers. Despite these limitations, this review provides a comprehensive overview of the hazards encountered in the workplace by health care workers in LMICs.

\section{Conclusions}

Large proportions of health care workers in LMICs are occupationally exposed to a wide range of hazards. Safety measures and risk reduction strategies in these countries are suboptimal, mainly due to resource limitations. Health care workers need to be protected from occupational hazards because these hazards have the potential to cause diseases and injuries and can adversely impact the retention of health care workers and the quality of care provided. Health care worker retention is of particular importance in LMICs since these countries already face a shortage of health care workers. Political commitment towards making occupational health and safety a priority public health issue is necessary to ensure the safety of health care workers in LMICs. Although research on occupational hazards among health care workers in these countries has increased considerably in the last decade, most of this work is on biological hazards. More research is needed on the other types of occupational hazards.

Supplementary Materials: The following are available online at https:/ / www.mdpi.com/1660-460 1/18/5/2603/s1, Table S1: Search strategy for Medline (Ovid) (date of search: 1 May 2020).

Author Contributions: R.R. developed the search strategy; screened, extracted and analysed the data; and prepared the manuscript. S.E.-Z., N.D., B.D.R. and L.F. contributed to the development of the search strategy, screening and extracting the data, and manuscript revision. All authors have read and agreed to the published version of the manuscript.

Funding: R.R. is supported by the Australian Government Research Training Program Scholarship.

Institutional Review Board Statement: Not applicable.

Informed Consent Statement: Not applicable.

Data Availability Statement: All data are presented in this article. Researchers can contact authors regarding any request about the data.

Conflicts of Interest: The authors declare no conflict of interest.

\section{References}

1. Vecchio, D.; Sasco, A.J.; Cann, C.I. Occupational risk in health care and research. Am. J. Ind. Med. 2003, 43, 369-397. [CrossRef] [PubMed]

2. The Lancet. COVID-19: Protecting health-care workers. Lancet 2020, 395, 922. [CrossRef]

3. McDiarmid, M.A. Hazards of the health care sector: Looking beyond infectious disease. Ann. Glob. Health $2014,80,315-319$. [CrossRef]

4. Coggon, D.; Harris, E.; Poole, J.; Palmer, K. Mortality of workers exposed to ethylene oxide: Extended follow up of a British cohort. Occup. Environ. Med. 2004, 61, 358-362. [CrossRef]

5. Ratner, P.A.; Spinelli, J.J.; Beking, K.; Lorenzi, M.; Chow, Y.; Teschke, K.; Le, N.D.; Gallagher, R.P.; Dimich-Ward, H. Cancer incidence and adverse pregnancy outcome in registered nurses potentially exposed to antineoplastic drugs. BMC Nurs. 2010, 9, 15. [CrossRef]

6. Vaughan, T.L.; Stewart, P.A.; Teschke, K.; Lynch, C.F.; Swanson, G.M.; Lyon, J.L.; Berwick, M. Occupational exposure to formaldehyde and wood dust and nasopharyngeal carcinoma. Occup. Environ. Med. 2000, 57, 376-384. [CrossRef]

7. Arif, A.A.; Delclos, G.L. Association between cleaning-related chemicals and work-related asthma and asthma symptoms among healthcare professionals. Occup. Environ. Med. 2012, 69, 35-40. [CrossRef] [PubMed] 
8. Trapé, M.; Schenck, P.; Warren, A. Latex gloves use and symptoms in health care workers 1 year after implementation of a policy restricting the use of powdered gloves. Am. J. Infect. Control 2000, 28, 352-358. [CrossRef] [PubMed]

9. Davis, K.G.; Kotowski, S.E. Prevalence of musculoskeletal disorders for nurses in hospitals, long-term care facilities, and home health care: A comprehensive review. Hum. Factors 2015, 57, 754-792. [CrossRef]

10. Phillips, J.P. Workplace violence against health care workers in the United States. N. Engl. J. Med. 2016, 374, 1661-1669. [CrossRef] [PubMed]

11. Maslach, C. Burnout: The Cost of Caring; Malor Books: Cambridge, MA, USA, 2003.

12. National Institute of Occupational Health and Safety. State of the Sector: Healthcare and Social Assistance; Centers for Disease Control and Prevention: Atlanta, GA, USA, 2009.

13. Nuwayhid, I.A. Occupational health research in developing countries: A partner for social justice. Am. J. Public Health 2004, 94, 1916-1921. [CrossRef]

14. Ingersoll, G.L.; Olsan, T.; Drew-Cates, J.; DeVinney, B.C.; Davies, J. Nurses' job satisfaction, organizational commitment, and career intent. J. Nurs. Admin. 2002, 32, 250-263. [CrossRef]

15. Liese, B.; Dussault, G. The State of the Health Workforce in Sub-Saharan Africa: Evidence of Crisis and Analysis of Contributing Factors; The World Bank: Washington, DC, USA, 2004.

16. Owie, H.; Apanga, P. Occupational health hazards prevailing among healthcare workers in developing countries. J. AIDS Clin. Res. 2016, 7, 596.

17. Arksey, H.; O'Malley, L. Scoping studies: Towards a methodological framework. Int. J. Soc. Res. Methodol. 2005, 8, 19-32. [CrossRef]

18. Daudt, H.M.; van Mossel, C.; Scott, S.J. Enhancing the scoping study methodology: A large, inter-professional team's experience with Arksey and O'Malley's framework. BMC Med. Res. Methodol. 2013, 13, 1-9. [CrossRef]

19. Levac, D.; Colquhoun, H.; O’Brien, K.K. Scoping studies: Advancing the methodology. Implement. Sci. 2010, 5, 69. [CrossRef]

20. Colquhoun, H.L.; Levac, D.; O’Brien, K.K.; Straus, S.; Tricco, A.C.; Perrier, L.; Kastner, M.; Moher, D. Scoping reviews: Time for clarity in definition, methods, and reporting. J. Clin. Epidemiol. 2014, 67, 1291-1294. [CrossRef]

21. Peters, M.; Godfrey, C.; McInerney, P.; Soares, C.B.; Khalil, H.; Parker, D. Methodology for JBI Scoping Reviews. The Joanna Briggs Institute Reviewers' Manual 2015; The Joanna Briggs Institute: Adelaide, Australia, 2015.

22. Tricco, A.C.; Lillie, E.; Zarin, W.; O’Brien, K.K.; Colquhoun, H.; Levac, D.; Moher, D.; Peters, M.D.; Horsley, T.; Weeks, L. PRISMA extension for scoping reviews (PRISMA-ScR): Checklist and explanation. Ann. Intern. Med. 2018, 169, 467-473. [CrossRef] [PubMed]

23. World Health Organization. Sources and Classification of Health Workforce Statistics; WHO: Geneva, Switzerland, 2008.

24. World Bank. World Bank Country Classification 2020. Available online: https://datahelpdesk.worldbank.org/knowledgebase/ articles/906519-world-bank-country-and-lending-groups (accessed on 17 April 2020).

25. Joshi, R.; Reingold, A.L.; Menzies, D.; Pai, M. Tuberculosis among health-care workers in low-and middle-income countries: A systematic review. PLoS Med. 2006, 3, e494. [CrossRef]

26. World Health Organization; International Labour Organization. Caring for Those Who Care: National Programmes for Occupational Health for Health Workers. Policy Brief; World Health Organization: Geneva, Switzerland, 2020.

27. Cavalcante, N.J.F.; Abreu, E.S.; Fernandes, M.E.L.; Richtmann, R.; Piovesana, M.N.; Yamada, F.T.; Carvalho, E.S. Risk of health care professionals acquiring HIV infection in Latin America. AIDS Care 1991, 3, 311-316. [CrossRef]

28. Adegboye, A.A.; Moss, G.B.; Soyinka, F.; Kreiss, J.K. The epidemiology of needlestick and sharp instrument accidents in a Nigerian hospital. Infect. Control Hosp. Epidemiol. 1994, 15, 27-31. [CrossRef]

29. Olubuyide, I. Doctors at risk of hepatitis B and HIV infection from patients in Nigeria. J. Roy. Soc. Health 1996, 116, 157-160. [CrossRef] [PubMed]

30. Gumodoka, B.; Favot, I.; Berege, Z.; Dolmans, W. Occupational exposure to the risk of HIV infection among health care workers in Mwanza Region, United Republic of Tanzania. Bull. World Health Organ. 1997, 75, 133-140.

31. Khuri-Bulos, N.A.; Toukan, A.; Mahafzah, A.; Al Adham, M.; Faori, I.; Khader, I.A.; Rumeileh, Z.I.A. Epidemiology of needlestick and sharp injuries at a university hospital in a developing country: A 3-year prospective study at the Jordan University Hospital, 1993 through 1995. Am. J. Infect. Control 1997, 25, 322-329. [CrossRef]

32. Gounden, Y.P.; Moodley, J. Exposure to human immunodeficiency virus among healthcare workers in South Africa. Int. J. Gynecol. Obstet. 2000, 69, 265-270. [CrossRef]

33. Phipps, W.; Honghong, W.; Min, Y.; Burgess, J.; Pellico, L.; Watkins, C.W.; Guoping, H.; Williams, A. Risk of medical sharps injuries among Chinese nurses. Am. J. Infect. Control 2002, 30, 277-282. [CrossRef] [PubMed]

34. Talaat, M.; Kandeel, A.; El-Shoubary, W.; Bodenschatz, C.; Khairy, I.; Oun, S.; Mahoney, F.J. Occupational exposure to needlestick injuries and hepatitis B vaccination coverage among health care workers in Egypt. Am. J. Infect. Control 2003, 31, 469-474. [CrossRef]

35. Kermode, M.; Jolley, D.; Langkham, B.; Thomas, M.S.; Crofts, N. Occupational exposure to blood and risk of bloodborne virus infection among health care workers in rural north Indian health care settings. Am. J. Infect. Control 2005, 33, 34-41. [CrossRef] [PubMed]

36. Kermode, M.; Jolley, D.; Langkham, B.; Thomas, M.S.; Holmes, W.; Gifford, S.M. Compliance with Universal/Standard Precautions among health care workers in rural north India. Am. J. Infect. Control 2005, 33, 27-33. [CrossRef] [PubMed] 
37. Nsubuga, F.M.; Jaakkola, M.S. Needle stick injuries among nurses in sub-Saharan Africa. Trop. Med. Int. Health 2005, 10, 773-781. [CrossRef]

38. Obi, S.; Waboso, P.; Ozumba, B. HIV/AIDS: Occupational risk, attitude and behaviour of surgeons in Southeast Nigeria. Int. J. STD AIDS 2005, 16, 370-373.

39. Chelenyane, M.; Endacott, R. Self-reported infection control practices and perceptions of HIV/AIDS risk amongst emergency department nurses in Botswana. Accid. Emerg. Nurs. 2006, 14, 148-154. [CrossRef]

40. Akinleye, A.A.; Omokhodion, F.O. Work practices of primary health care workers in urban and rural health facilities in south-west Nigeria. Aust. J. Rural Health 2008, 16, 47-48. [CrossRef] [PubMed]

41. Okeke, E.; Ladep, N.; Agaba, E.; Malu, A. Hepatitis B vaccination status and needle stick injuries among medical students in a Nigerian university. Niger. J. Med. 2008, 17, 330-332. [CrossRef]

42. Taegtmeyer, M.; Suckling, R.; Nguku, P.; Meredith, C.; Kibaru, J.; Chakaya, J.M.; Muchela, H.; Gilks, C. Working with risk: Occupational safety issues among healthcare workers in Kenya. AIDS Care 2008, 20, 304-310. [CrossRef]

43. Chen, L.; Zhang, M.; Yan, Y.; Miao, J.; Lin, H.; Zhang, Y.; Wang, H.; Du, X.; Li, T. Sharp object injuries among health care workers in a Chinese province. AAOHN J. 2009, 57, 13-16. [CrossRef]

44. Simon, L.P. Prevention and management of needlestick injury in Delhi. Br. J. Nurs. 2009, 18, 252-256. [CrossRef]

45. Chakravarthy, M.; Singh, S.; Arora, A.; Sengupta, S.; Munshi, N. The epinet data of four Indian hospitals on incidence of exposure of healthcare workers to blood and body fluid: A multicentric prospective analysis. Indian J. Med. Sci. 2010, 64, 540-548. [CrossRef]

46. Yacoub, R.; Al Ali, R.; Moukeh, G.; Lahdo, A.; Mouhammad, Y.; Nasser, M. Hepatitis B vaccination status and needlestick injuries among healthcare workers in Syria. J. Glob. Infect. Dis. 2010, 2, 28-34. [CrossRef] [PubMed]

47. Sangwan, B.; Kotwal, A.; Verma, A. Occupational exposure to blood and body fluids amongst health care workers in a teaching hospital of the armed forces. Med. J. Armed Forces India 2011, 67, 21-24. [CrossRef]

48. Irmak, Z. Needlestick and sharps injury among nurses at a state hospital in Turkey. Aust. J. Adv. Nurs. 2012, 30, 48-55.

49. Nasim, S.; Shahid, A.; Mustufa, M.A.; Arain, G.M.; Ali, G.; Taseer, I.-U.-H.; Talreja, K.L.; Firdous, R.; Iqbal, R.; Siddique, S.A.; et al. Biosafety perspective of clinical laboratory workers: A profile of Pakistan. J. Infect. Dev. Ctries. 2012, 6, 611-619. [CrossRef]

50. Omorogbe, V.E.; Omuemu, V.O.; Isara, A.R. Injection safety practices among nursing staff of mission hospitals in Benin City, Nigeria. Ann. Afr. Med. 2012, 11, 36-41.

51. Phillips, E.K.; Simwale, O.J.; Chung, M.J.; Parker, G.; Perry, J.; Jagger, J.C. Risk of bloodborne pathogen exposure among Zambian healthcare workers. J. Infect. Public Health 2012, 5, 244-249. [CrossRef]

52. Sethi, A.K.; Acher, C.W.; Kirenga, B.; Mead, S.; Donskey, C.J.; Katamba, A. Infection Control Knowledge, Attitudes, and Practices among Healthcare Workers at Mulago Hospital, Kampala, Uganda. Infect Control Hosp. Epidemiol. 2012, 33, 917-923. [CrossRef]

53. Abkar, M.A.A.; Wahdan, I.M.H.; Sherif, A.A.R.; Raja'a, Y.A. Unsafe injection practices in Hodeidah governorate, Yemen. J. Infect. Public Health 2013, 6, 252-260. [CrossRef]

54. Afridi, A.A.K.; Kumar, A.; Sayani, R. Needle stick injuries-risk and preventive factors: A study among health care workers in tertiary care hospitals in Pakistan. Glob. J. Health Sci. 2013, 5, 85-92. [CrossRef] [PubMed]

55. Rajkumari, N.; Thanbuana, B.T.; John, N.V.; Gunjiyal, J.; Mathur, P.; Misra, M.C. A prospective look at the burden of sharps injuries and splashes among trauma health care workers in developing countries: True picture or tip of iceberg. Injury 2014, 45, 1470-1478. [CrossRef] [PubMed]

56. Bekele, T.; Gebremariam, A.; Ahmed, K. Attitude, reporting behavour and management practice of occupational needle stick and sharps injuries among hospital healthcare workers in Bale zone, Southeast Ethiopia: A cross-sectional study. J. Occup. Med. Toxicol. 2015, 10, 42. [CrossRef]

57. Priya, N.L.; Krishnan, K.U.; Jayalakshmi, G.; Vasanthi, S. An analysis of multimodal occupational exposure leading to blood borne infections among health care workers. Indian J. Pathol. Microbiol. 2015, 58, 66-68. [CrossRef] [PubMed]

58. Sabermoghaddam, M.; Sarbaz, M.; Lashkardoost, H.; Kaviani, A.; Eslami, S.; Rezazadeh, J. Incidence of occupational exposure to blood and body fluids and measures taken by health care workers before and after exposure in regional hospitals of a developing country: A multicenter study. Am. J. Infect. Control 2015, 43, 1137-1138. [CrossRef] [PubMed]

59. Türe, Z.; Ulu Kiliç, A.; Cevahir, F.; Altun, D.; Özhan, E.; Alp, E. Predictive factors for percutaneous and mucocutaneous exposure among healthcare workers in a developing country. J. Epidemiol. Glob. Health 2016, 6, 141-146. [CrossRef] [PubMed]

60. Konlan, K.D.; Aarah-Bapuah, M.; Kombat, J.M.; Wuffele, G.M. The level of nurses' knowledge on occupational post exposure to Hepatitis B infection in the Tamale metropolis, Ghana. BMC Health Serv. Res. 2017, 17, 1-7. [CrossRef]

61. Matsubara, C.; Sakisaka, K.; Sychareun, V.; Phensavanh, A.; Ali, M. Prevalence and risk factors of needle stick and sharp injury among tertiary hospital workers, Vientiane, Lao PDR. J. Occup. Health 2017, 59, 581-585. [CrossRef] [PubMed]

62. Geberemariyam, B.S.; Donka, G.M.; Wordofa, B. Assessment of knowledge and practices of healthcare workers towards infection prevention and associated factors in healthcare facilities of West Arsi District, Southeast Ethiopia: A facility-based cross-sectional study. Arch. Public Health 2018, 76, 69. [CrossRef] [PubMed]

63. Mandić, B.; Mandić-Rajčević, S.; Marković-Denić, L.; Bulat, P. Occupational exposure to blood and bodily fluids among healthcare workers in Serbian general hospitals. Arh. Hig. Rada Toksikol. 2018, 69, 61-68. [CrossRef] [PubMed] 
64. Hebo, H.J.; Gemeda, D.H.; Abdusemed, K.A. Hepatitis B and C viral infection: Prevalence, knowledge, attitude, practice, and occupational exposure among healthcare workers of Jimma University Medical Center, southwest Ethiopia. Sci. World J. 2019, 2019, 11. [CrossRef]

65. Lien, L.T.; Hang, N.T.L.; Kobayashi, N.; Yanai, H.; Toyota, E.; Sakurada, S.; Huu Thuong, P.; Cuong, V.C.; Nanri, A.; Mizoue, T.; et al. Prevalence and risk factors for tuberculosis infection among hospital workers in Hanoi, Viet Nam. PLoS ONE 2009, 4, e6798. [CrossRef]

66. Mathew, A.; David, T.; Thomas, K.; Kuruvilla, P.J.; Balaji, V.; Jesudason, M.V.; Samuel, P. Risk factors for tuberculosis among health care workers in South India: A nested case-control study. J. Clin. Epidemiol. 2013, 66, 67-74. [CrossRef] [PubMed]

67. Wei, Z.; Yang, M.; Quan, B.; Wang, Y.; Wu, Y.; Ji, B. Prevalence of latent tuberculosis infection among healthcare workers in China as detected by two interferon-gamma release assays. J. Hosp. Infect. 2013, 84, 323-325. [CrossRef]

68. Whitaker, J.; Mirtskhulava, V.; Kipiani, M.; Harris, D.; Tabagari, N.; Kempker, R.; Blumberg, H. Prevalence and incidence of latent tuberculosis infection in Georgian healthcare workers. PLoS ONE 2013, 8, e58202. [CrossRef]

69. Tudor, C.; Van der Walt, M.; Margot, B.; Dorman, S.E.; Pan, W.K.; Yenokyan, G.; Farley, J.E. Tuberculosis among health care workers in KwaZulu-Natal, South Africa: A retrospective cohort analysis. BMC Public Health 2014, 14, 891. [CrossRef]

70. El-Sokkary, R.; Abu-Taleb, A.; El-Seifi, O.; Zidan, H.; Mortada, E.; El-Hossary, D.; Farag, S. Assessing the prevalence of latent tuberculosis among health care providers in Zagazig city, Egypt using Tuberculin skin test and Quantiferon-TB gold in-tube test. Cent. Eur. J. Public Health 2015, 23, 324-330. [PubMed]

71. Tudor, C.; Van der Walt, M.L.; Margot, B.; Dorman, S.E.; Pan, W.K.; Yenokyan, G.; Farley, J.E. Occupational risk factors for tuberculosis among healthcare workers in KwaZulu-Natal, South Africa. Clin. Infect. Dis. 2016, 62, S255-S261. [CrossRef]

72. He, W.; Chen, B.-D.; Lv, Y.; Zhou, Z.; Xu, J.-P.; Lv, P.-X.; Zhou, X.-H.; Ning, F.-G.; Li, C.-H.; Wang, D.-P. Use of low-dose computed tomography to assess pulmonary tuberculosis among healthcare workers in a tuberculosis hospital. Infect. Dis. Poverty 2017, 6, 68. [CrossRef]

73. Erawati, M.; Andriany, M. The prevalence and demographic risk factors for latent tuberculosis infection (LTBI) among healthcare workers in Semarang, Indonesia. J. Multidiscip. Healthc. 2020, 13, 197-206. [CrossRef]

74. Kisa, A.; Dziegielewski, S.F.; Ates, M. Sexual harassment and its consequences: A study within Turkish hospitals. J. Health Soc. Policy 2002, 15, 77-94. [CrossRef] [PubMed]

75. Kamchuchat, C.; Chongsuvivatwong, V.; Oncheunjit, S.; Yip, T.W.; Sangthong, R. Workplace violence directed at nursing staff at a general hospital in Southern Thailand. J. Occup. Health 2008, 50, 201-207. [CrossRef]

76. Aydin, B.; Kartal, M.; Midik, O.; Buyukakkus, A. Violence against general practitioners in Turkey. J. Interpers. Violence 2009, 24, 1980-1995. [CrossRef] [PubMed]

77. Gimeno, D.; Barrientos-Gutiérrez, T.; Burau, K.D.; Felknor, S.A. Safety climate and verbal abuse among public hospital-based workers in Costa Rica. Work 2012, 42, 29-38. [CrossRef]

78. Atan, Ş.U.; Baysan Arabaci, L.; Sirin, A.; Isler, A.; Donmez, S.; Unsal Guler, M.; Oflaz, U.; Yalcinkaya Ozdemir, G.; Yazar Tasbasi, F. Violence experienced by nurses at six university hospitals in T urkey. J. Psychiatr. Ment. Health Nurs. 2013, 20, 882-889. [CrossRef] [PubMed]

79. Khademloo, M.; Moonesi, F.S.; Gholizade, H. Health care violence and abuse towards nurses in hospitals in north of Iran. Glob. J. Health Sci. 2013, 5, 211-216. [CrossRef] [PubMed]

80. Da Silva, A.T.C.; Peres, M.F.T.; de Souza Lopes, C.; Schraiber, L.B.; Susser, E.; Menezes, P.R. Violence at work and depressive symptoms in primary health care teams: A cross-sectional study in Brazil. Soc. Psychiatry Psychiatr. Epidemiol. 2015, 50, 1347-1355. [CrossRef]

81. Baig, L.A.; Shaikh, S.; Polkowski, M.; Ali, S.K.; Jamali, S.; Mazharullah, L.; Soomro, M.; Kumari, B.; Memon, S.; Maheshwari, G. Violence against health care providers: A mixed-methods study from Karachi, Pakistan. J. Emerg. Med. 2018, 54, 558-566. [CrossRef] [PubMed]

82. Zhao, S.; Xie, F.; Wang, J.; Shi, Y.; Zhang, S.; Han, X.; Sun, Z.; Shi, L.; Li, Z.; Mu, H.; et al. Prevalence of workplace violence against Chinese nurses and its association with mental health: A cross-sectional survey. Arch. Psychiatr. Nurs. 2018, 32, $242-247$. [CrossRef] [PubMed]

83. Abate, A.; Abebaw, D.; Birhanu, A.; Zerihun, A.; Assefa, D. Prevalence and associated factors of violence against hospital staff at Amanuel Mental Specialized Hospital in Addis Ababa, Ethiopia. Psychiatry J. 2019, 2019, 11. [CrossRef]

84. Yenealem, D.G.; Woldegebriel, M.K.; Olana, A.T.; Mekonnen, T.H. Violence at work: Determinants \& prevalence among health care workers, northwest Ethiopia: An institutional based cross sectional study. Ann. Occup. Environ. Med. 2019, 31, 8.

85. Hacer, T.Y.; Ali, A. Burnout in physicians who are exposed to workplace violence. J. Forensic Leg. Med. 2020, 69, 101874. [CrossRef]

86. Ashkar, K.; Romani, M.; Musharrafieh, U.; Chaaya, M. Prevalence of burnout syndrome among medical residents: Experience of a developing country. Postgrad. Med. J. 2010, 86, 266-271. [CrossRef] [PubMed]

87. Ayala, E.; Carnero, A.M. Determinants of burnout in acute and critical care military nursing personnel: A cross-sectional study from Peru. PLoS ONE 2013, 8, e54408. [CrossRef]

88. Zubairi, A.J.; Noordin, S. Factors associated with burnout among residents in a developing country. Ann. Med. Surg. 2016, 6, 60-63. [CrossRef] [PubMed]

89. Colindres, C.V.; Bryce, E.; Coral-Rosero, P.; Ramos-Soto, R.M.; Bonilla, F.; Yassi, A. Effect of effort-reward imbalance and burnout on infection control among Ecuadorian nurses. Int. Nurs. Rev. 2018, 65, 190-199. [CrossRef] [PubMed] 
90. Khan, F.A.; Shamim, M.H.; Ali, L.; Taqi, A. Evaluation of job stress and burnout among anesthesiologists working in academic institutions in 2 major cities in Pakistan. Anesth. Analg. 2019, 128, 789-795. [CrossRef]

91. Mumbwe, M.C.; McIsaac, D.; Jarman, A.; Bould, M.D. A cross-sectional survey to determine the prevalence of burnout syndrome among anesthesia providers in Zambian hospitals. Anesth. Analg. 2020, 130, 310-317. [CrossRef]

92. Li, J.; Fu, H.; Hu, Y.; Shang, L.; Wu, Y.; Kristensen, T.S.; Mueller, B.H.; Hasselhorn, H.M. Psychosocial work environment and intention to leave the nursing profession: Results from the longitudinal Chinese NEXT study. Scand. J. Public Health 2010, 38, 69-80. [CrossRef]

93. Ayamolowo, S.J.; Irinoye, O.; Oladoyin, M.A. Job satisfaction and work environment of primary health care nurses in Ekiti State, Nigeria: An exploratory study. Int. J. Caring Sci. 2013, 6, 531-542.

94. Ogunlade, O.; Ogunfowokan, A. Clinical nurses' satisfaction with night shift in selected hospitals in Ile-Ife, Osun state, Nigeria. Int. J. Caring Sci. 2014, 7, 129-139.

95. Ayalew, E.; Workineh, Y. Job satisfaction and associated factors among nurses in Bahir Dar city administrative, North West Ethiopia, 2017. BMC Res. Notes 2019, 12,319. [CrossRef]

96. Smith, D.R.; Wei, N.; Zhao, L.; Wang, R.-S. Musculoskeletal complaints and psychosocial risk factors among Chinese hospital nurses. Occup. Med. 2004, 54, 579-582. [CrossRef] [PubMed]

97. Tezel, A. Musculoskeletal complaints among a group of Turkish nurses. Int. J. Neurosci. 2005, 115, 871-880. [CrossRef]

98. Fabunmi, A.A.; Oworu, J.O.; Odunaiya, N.A. Prevalence of musculoskeletal disorders among nurses in University College Hospital, Ibadan. West Afr. J. Nurs. 2008, 19, 21-25.

99. De Castro, A.B.; Cabrera, S.L.; Gee, G.C.; Fujishiro, K.; Tagalog, E.A. Occupational health and safety issues among nurses in the Philippines. Workplace Health Saf. 2009, 57, 149-157.

100. Karahan, A.; Kav, S.; Abbasoglu, A.; Dogan, N. Low back pain: Prevalence and associated risk factors among hospital staff. J. Adv. Nurs. 2009, 65, 516-524. [CrossRef]

101. Mehrdad, R.; Dennerlein, J.T.; Haghighat, M.; Aminian, O. Association between psychosocial factors and musculoskeletal symptoms among Iranian nurses. Am. J. Ind. Med. 2010, 53, 1032-1039. [CrossRef]

102. Tinubu, B.M.S.; Mbada, C.E.; Oyeyemi, A.L.; Fabunmi, A.A. Work-Related Musculoskeletal Disorders among Nurses in Ibadan, South-west Nigeria: A cross-sectional survey. BMC Musculoskelet. Disord. 2010, 11, 12. [CrossRef] [PubMed]

103. Arsalani, N.; Fallahi-Khoshknab, M.; Josephson, M.; Lagerström, M. Musculoskeletal disorders and working conditions among Iranian nursing personnel. Int. J. Occup. Saf. Ergon. 2014, 20, 671-680. [CrossRef]

104. Barzideh, M.; Choobineh, A.R.; Tabatabaee, H.R. Job stress dimensions and their relationship to musculoskeletal disorders in Iranian nurses. Work 2014, 47, 423-429. [CrossRef] [PubMed]

105. Munabi, I.G.; Buwembo, W.; Kitara, D.L.; Ochieng, J.; Mwaka, E.S. Musculoskeletal disorder risk factors among nursing professionals in low resource settings: A cross-sectional study in Uganda. BMC Nurs. 2014, 13, 7. [CrossRef]

106. Yasobant, S.; Rajkumar, P. Work-related musculoskeletal disorders among health care professionals: A cross-sectional assessment of risk factors in a tertiary hospital, India. Indian J. Occup. Environ. Med. 2014, 18, 75-81. [CrossRef]

107. Abaraogu, U.O.; Ezema, C.I.; Nwosu, C.K. Job stress dimension and work-related musculoskeletal disorders among southeast Nigerian physiotherapists. Int. J. Occup. Saf. Ergon. 2017, 23, 404-409. [CrossRef] [PubMed]

108. Amin, N.A.; Quek, K.F.; Oxley, J.A.; Noah, R.; Nordin, R. Emotional distress as a predictor of work-related musculoskeletal disorders in Malaysian nursing professionals. Int. J. Occup. Environ. Med. 2018, 9, 69-78. [CrossRef]

109. Dlungwane, T.; Voce, A.; Knight, S. Prevalence and factors associated with low back pain among nurses at a regional hospital in KwaZulu-Natal, South Africa. Health SA Gesondheid 2018, 23, a1028. [CrossRef] [PubMed]

110. Ike, E.; Olawumi, J. The prevalence, risk factors and coping measures of back pain among nurses in Federal Medical Centre, Abeokuta, Ogun state, Nigeria. Int. J. Caring Sci. 2018, 11, 955-968.

111. Luan, H.D.; Hai, N.T.; Xanh, P.T.; Giang, H.T.; Thuc, P.V.; Hong, N.M.; Khue, P.M. Musculoskeletal disorders: Prevalence and associated factors among district hospital nurses in Haiphong, Vietnam. Biomed. Res. Int. 2018, e1-e9. [CrossRef]

112. Dong, H.; Zhang, Q.; Liu, G.; Shao, T.; Xu, Y. Prevalence and associated factors of musculoskeletal disorders among Chinese healthcare professionals working in tertiary hospitals: A cross-sectional study. BMC Musculoskelet. Disord. 2019, $20,175$. [CrossRef] [PubMed]

113. Baykal, U.; Seren, S.; Sokmen, S. A description of oncology nurses' working conditions in Turkey. Eur. J. Oncol. Nurs. 2009, 13, 368-375. [CrossRef]

114. Agrawal, A.; Bhatt, N.; Kk, S.; Singh, K.; Chaudhary, H.; Asawa, K. Prevalence of allergy to latex gloves among dental professionals in Udaipur, Rajasthan, India. Oral Health Prev. Dent. 2010, 8, 345-350.

115. Amarasekera, M.; Rathnamalala, N.; Samaraweera, S.; Jinadasa, M. Prevalence of latex allergy among healthcare workers. Int. J. Occup. Med. Environ. Health 2010, 23, 391-396. [CrossRef]

116. Phaswana, S.M.; Naidoo, S. The prevalence of latex sensitisation and allergy and associated risk factors among healthcare workers using hypoallergenic latex gloves at King Edward VIII Hospital, KwaZulu-Natal South Africa: A cross-sectional study. BMJ Open 2013, 3, e002900. [CrossRef]

117. Supapvanich, C.; Povey, A.C.; de Vocht, F. Respiratory and dermal symptoms in Thai nurses using latex products. Occup. Med. 2013, 63, 425-428. [CrossRef] 
118. Köse, S.; Mandiracioğlu, A.; Tatar, B.; Gül, S.; Erdem, M. Prevalence of latex allergy among healthcare workers in Izmir (Turkey). Cent. Eur. J. Public Health 2014, 22, 262-265. [CrossRef]

119. Supapvanich, C.; Povey, A.; de Vocht, F. Latex sentization and risk factors in female nurses in Thai governmental hospitals. Int. J. Occup. Med. Environ. Health 2014, 27, 93-103. [CrossRef]

120. Abbasi, K.; Hazrati, M.; Mohammadbeigi, A.; Ansari, J.; Sajadi, M.; Hosseinnazzhad, A.; Moshiri, E. Protection behaviors for cytotoxic drugs in oncology nurses of chemotherapy centers in Shiraz hospitals, South of Iran. Indian J. Med. Paediatr. Oncol. 2016, 37, 227-231.

121. Elshaer, N. Adverse health effects among nurses and clinical pharmacists handling antineoplastic drugs: Adherence to exposure control methods. J. Egypt. Public Health Assoc. 2017, 92, 144-155. [CrossRef]

122. Alehashem, M.; Baniasadi, S. Important exposure controls for protection against antineoplastic agents: Highlights for oncology health care workers. Work 2018, 59, 165-172. [CrossRef]

123. Bayraktar-Ekincioglu, A.; Korubük, G.; Demirkan, K. An evaluation of chemotherapy drug preparation process in hospitals in Turkey-A pilot study. J. Oncol. Pharm. Pract. 2018, 24, 563-573. [CrossRef] [PubMed]

124. Aluko, O.O.; Adebayo, A.E.; Adebisi, T.F.; Ewegbemi, M.K.; Abidoye, A.T.; Popoola, B.F. Knowledge, attitudes and perceptions of occupational hazards and safety practices in Nigerian healthcare workers. BMC Res. Notes 2016, 9, 71. [CrossRef]

125. Tait, F.N.; Mburu, C.; Gikunju, J. Occupational safety and health status of medical laboratories in Kajiado County, Kenya. Pan Afr. Med. J. 2018, 29, 65-81. [PubMed]

126. Lee, R. Occupational transmission of bloodborne diseases to healthcare workers in developing countries: Meeting the challenges. J. Hosp. Infect. 2009, 72, 285-291. [CrossRef]

127. Garner, J.S. Guideline for isolation precautions in hospitals. Infect. Cont. Hosp. Epidemiol. 1996, 17, 54-80. [CrossRef]

128. Menzies, D.; Joshi, R.; Pai, M. Risk of tuberculosis infection and disease associated with work in health care settings. Int. J. Tuberc. Lung Dis. 2007, 11, 593-605.

129. Jesudas, C.D.; Thangakunam, B. Tuberculosis risk in health care workers. Indian J. Chest Dis. Allied Sci. 2013, 55, 149-154.

130. Lanctôt, N.; Guay, S. The aftermath of workplace violence among healthcare workers: A systematic literature review of the consequences. Aggress. Violent Behav. 2014, 19, 492-501. [CrossRef]

131. Maslach, C.; Jackson, S.E.; Leiter, M.P. Maslach Burnout Inventory Manual, 4th ed.; Mind Garden Inc.: Menlo Park, CA, USA, 2016.

132. McHugh, M.D.; Kutney-Lee, A.; Cimiotti, J.P.; Sloane, D.M.; Aiken, L.H. Nurses' widespread job dissatisfaction, burnout, and frustration with health benefits signal problems for patient care. Health Aff. 2011, 30, 202-210. [CrossRef]

133. World Health Organization. Health Workforce Requirements for Universal Coverage and the Sustainable Development Goals; WHO: Geneva, Switzerland, 2016.

134. Andersson, G.B. Epidemiological features of chronic low-back pain. Lancet 1999, 354, 581-585. [CrossRef]

135. Vieira, E.R.; Schneider, P.; Guidera, C.; Gadotti, I.C.; Brunt, D. Work-related musculoskeletal disorders among physical therapists: A systematic review. J. Back Musculoskelet. Rehabil. 2016, 29, 417-428. [CrossRef]

136. Epstein, S.; Sparer, E.H.; Tran, B.N.; Ruan, Q.Z.; Dennerlein, J.T.; Singhal, D.; Lee, B.T. Prevalence of work-related musculoskeletal disorders among surgeons and interventionalists: A systematic review and meta-analysis. JAMA Surg. 2018, 153 , e174947. [CrossRef]

137. Sakzewski, L.; Naser-ud-Din, S. Work-related musculoskeletal disorders in dentists and orthodontists: A review of the literature. Work 2014, 48, 37-45. [CrossRef]

138. McDiarmid, M.A. Advocating for the health worker. Ann. Glob. Health 2019, 85, 16. [CrossRef] 